\title{
The semantics and pragmatics of composite mood marking: The non-Pama-Nyungan languages of northern Australia
}

\author{
JEAN-CHRISTOPHE VERSTRAETE
}

\begin{abstract}
This paper investigates a system of composite mood marking in the non-PamaNyungan languages of northern Australia, which generally mark modal meanings through combinations of prefixes and suffixes of the finite verb. The analysis focuses on the category of irrealis, which is typically marked with a specific prefix, and covers both meanings of counterfactuality (when combined with a past tense suffix) and of potentiality (when combined with non-past tense suffixes). The central problem in describing this category, as with irrealis categories more generally, is how to reconcile the feature of non-actualization found in the counterfactual uses with the feature of potentiality found in all other uses (including the counterfactual one). On the basis of the formal systematics of prefix-suffix combinations, as well as the internal semantic structure of counterfactual constructions, it is shown that non-actualization can be derived from past potentiality by general Gricean principles. In addition, this analysis suggests that some exceptional non-Pama-Nyungan systems that do not have an irrealis prefix can be diachronically related to the basic system with an irrealis prefix. The analysis proposed has implications for the more general typology of irrealis categories and for their relation with negation.
\end{abstract}

Keywords: counterfactuality, Gricean maxims, implicature, irrealis, modality, mood, negation, non-Pama-Nyungan, tense

\section{Introduction}

The non-Pama-Nyungan languages of northern Australia are generally characterized by morphologically complex verbs that add both prefixes and suffixes to the finite verb stem, ${ }^{1}$ as in the Wardaman example in (1) below, where the verb

1. Many non-Pama-Nyungan languages systematically use combinations of a finite (inflected) and a non-finite (non-inflected) verb to encode verbal meanings (see Schultze-Berndt 2000, 
is augmented with two prefixes (yi- and -nga-) and a suffix (-rri) expressing various categories of person, tense, and mood. The use of prefixes in addition to suffixes in verbal morphology is one of the structural features that sets the non-Pama-Nyungan languages apart from the other Australian languages, though the origin of this difference in shared descent or extensive diffusion is a matter of debate (see Dixon 2002, Evans 2003b).

(1) Wardaman (Yangmanic)

yi-nga-jejbarla-rri wu-munburra-wu

IRR-1sG/3sG-ask-PST $w u$-money-DAT

'I should have asked him for money.' (Merlan 1994: 188)

From a typological perspective, one interesting aspect of the morphologically complex verbs in these languages is the grammatical marking of mood, broadly defined as the grammatical expression of the speaker's assessment of the plausibility of propositions or the desirability of actions (a more detailed definition will be provided in Section 2.2). In the majority of non-PamaNyungan languages, mood is not marked in one specific slot in the morphological structure of the verb, but spread over at least two slots, marked by a combination of morphemes in a prefix and a suffix slot. In the Wardaman example in (1) above, for instance, the combination of an irrealis prefix with a past suffix serves to mark counterfactuality, i.e., the speaker's assessment that something should have happened but did not. The fact that both the prefix and the suffix element contribute to mood marking can be shown by comparing it with further examples like ( $2 a, b)$, where variations of morphemes in the same prefix and suffix slots mark different types of mood categories. The structures in (2a) illustrate how the same irrealis prefix ${ }^{2}$ can mark deontic mood (a judgement of (un)desirability) when combined with a present suffix (yini-wo-n), and apprehensive mood (a judgement of undesirable possibility) when used without a suffix (yayi-layi). The structure in (2b), finally, shows how the irrealis prefix is in paradigmatic contrast to a structure without a prefix, where a potential suffix (-yan) can mark epistemic mood (a judgement of possibility).

McGregor 2002). Whenever there is such a distinction, the discussion here will refer only to the finite element in the combination.

2. In this case, the prefix is morphologically fused with bound pronouns. In some languages (like Nyikina, for instance) this type of fusion has given rise to different "modal" and "nonmodal" series of pronouns rather than separate modal prefixes. I will, somewhat inaccurately, deal with such instances under the general label of "prefix" categories, because irrespective of fusion they still constitute the pre-verbal component of mood marking in a composite mood system. 
Wardaman (Yangmanic)
a. wonggo yini-wo-n
NEG IRR.2SG/3sG-give-PRS water-ABS IRR.3-die
wiyan yayi-layi
'You mustn't give him water, lest he die.' (Merlan 1994: 188)
b. nga-nyanga-yan wirrig
1SG-come-POT tomorrow
'I might come back tomorrow.' (Merlan 1994: 179)

Table 1 is a mini-paradigm that summarizes the mood meanings marked by the different combinations of prefixes and suffixes in the Wardaman examples in (1) and (2).

Table 1. Composite mood marking in the Wardaman examples (1)-(2)

\begin{tabular}{|l|l|l|}
\hline Prefix & Suffix & Modal meaning \\
\hline IRR & PST & Counterfactual \\
\cline { 2 - 3 } & PRES & Deontic \\
\cline { 2 - 3 } & $\varnothing$ & Apprehensive \\
\hline$\varnothing$ & POT & Epistemic \\
\hline
\end{tabular}

The Wardaman system described here is a good example of the way mood categories are marked on the verb in the majority of non-Pama-Nyungan languages. Like Wardaman, most non-Pama-Nyungan languages show a primary subdivision between an irrealis-type prefix and a realis-type prefix (or absence of a prefix, as in Wardaman): the latter is used in the majority of non-modalized structures, basically statements of fact, whereas the former covers a broad range of modal meanings, usually at least a counterfactual type of modality as in (1), and one or more of the epistemic, deontic, and apprehensive categories as in (2a). Within the broad semantic range covered by the irrealis prefix, moreover, there is usually a further subdivision of modal meanings in terms of combinations with different types of tense suffixes: as in (1) and (2a), the counterfactual type is usually set apart from the other types of modality in terms of a basic contrast between past and non-past tense suffixes.

Because of its formal compositionality, the system of mood marking found in the non-Pama-Nyungan languages is of considerable interest to the semantic typology of mood categories, especially the typology of irrealis. The grammaticized nature of the prefix-suffix combinations used to mark mood in these languages gives a good insight into the semantic building blocks of modal meanings: the mechanism of the combinations can be used as formal evidence for which types of meanings tend to be grouped together in a more general category of irrealis, and which semantic features distinguish further subcategories of irrealis. In this study, I will provide a detailed analysis of the systematics of 
composite mood marking in non-Pama-Nyungan languages, and I will use this analysis to tackle a number of more general questions in the semantic analysis of mood.

Specifically, I will focus on the nature of irreality and the viability of irrealis as a semantically coherent and crosslinguistically applicable category in the description of modality. One reason why irrealis may seem to be a less than useful semantic generalization in the analysis of mood (see, for instance, Bybee, Perkins, \& Pagliuca 1994 and Bybee 1998) is that it is apparently split between two conflicting definitions, one in terms of potential actualization of an event (which applies to deontic and apprehensive uses like (2a)), and another in terms of non-actualization of an event (which applies to counterfactual uses like (1)). On the basis of the formal evidence provided by the composite system of marking in the non-Pama-Nyungan languages, I will argue that the two apparently conflicting definitions can actually be unified in a principled way, because the feature of non-actualization can be explained as a pragmatically driven outgrowth of the basic semantics of potential actualization in a past temporal domain.

This argument will be elaborated in three steps. In Section 2, I will present the general formal characteristics of the system of composite mood marking as it is found in the majority of the languages in the sample, and I will identify the basic semantic tendencies in the system. In Section 3, I will deal with those uses that do not seem to fit in with the basic semantics of the system because they involve non-actualization, and I will use the formal systematics of the prefix-suffix combinations to show how such apparently unmotivated uses can be derived from the basic semantics of the system by more general pragmatic principles. In Section 4, I will show how this proposal allows us to come to a unified model of composite mood marking in the non-PamaNyungan languages, which integrates both the semantically deviant patterns and the formally deviant ones. In the concluding section, I will examine the implications of the non-Pama-Nyungan system for a number of more general questions in the analysis of mood, especially the nature and viability of irrealis as a crosslinguistically applicable category, and its relations with the domain of negation.

\section{Mood marking in non-Pama-Nyungan languages}

This study is based on a sample of twenty-eight non-Pama-Nyungan languages, which are listed in Appendix 1, together with the sources used for each language. The sample is meant to be as exhaustive as possible, in that it tries to take into account as many non-Pama-Nyungan families as possible (fourteen, based on the most recent account in Evans 2003b) for which reliable information is available. 
In this section, I will first provide an overview of the formal characteristics of composite mood marking that are common to most languages in the sample (Section 2.1) and then describe the basic semantic tendencies in the system (Section 2.2).

\subsection{Formal composition}

Of the twenty-eight non-Pama-Nyungan languages investigated here, there are twenty-four that use a system of composite mood marking like the Wardaman structures presented in (1) and (2), i.e., where mood is marked by a combination of prefixes and suffixes in the morphological structure of the finite verb. The languages that deviate from this general pattern either use only verbal suffixes ${ }^{3}$ to mark mood (Kayardild, Mara), or they use verbal suffixes in combination with a separate non-verbal auxiliary element (Wambaya, Yukulta). Thus, for instance, in the Kayardild structures in (3), deontic and epistemic meanings are marked with different suffixes (-nangku, -thu) but no prefixes, and in the Wambaya structures in (4), deontic and counterfactual meanings are marked by various separate non-verbal auxiliary elements (nyi-ng-a, gun-uja) in combination with different verbal suffixes $(-b a,-d i)$.

Kayardild (Tangkic)

a. ngurruwarra-wan-da yakuri wungi-i-nangku fishtrap-ORIG-NOM fish.NOM steal-MID-NEG.POT

'Fish from fishtraps must not be stolen.' (Evans 1995: 259)

b. niya bukawa-thu mungkiji-wu dulk-u

3sG.NOM die-POT Own-MPROP country-MPROP

'He will die in his own country.' (Evans 1995: 258)

(4) Wambaya (Mindi)

a. jiya-j-ba nyi-ng-a manganyma!

give-TH-FUT 2sG.A-1.O-NF tucker.III(ACC)

'Give me some tucker!' (Nordlinger 1998: 162)

b. wugbar-di gun-uja manganyma

cook-NF 3sG.M.A-NACT.PST tucker.III(ACC)

gujinganjanga-nka

mother.II(DAT)

'He should have cooked some tucker for his mother.' (Nordlinger 1998: 161)

3. This restriction applies only to mood marking in the verb. As pointed out by a reviewer, there may be other types of elements in the language that can be combined with mood marking on the verb to form complex types of mood: in the case of Kayardild, for instance, there is the typologically unusual option of marking mood as nominal case in addition to the system of verbal suffixation (see Evans 1995: 399-450). 
Table 2. The basic pattern of composite mood marking

\begin{tabular}{|c|c|c|}
\hline Prefix & Suffix & Modal meaning \\
\hline \multirow[b]{2}{*}{ Realis } & Past & \multirow{2}{*}{$\begin{array}{l}\text { Non-modal meanings and } \\
\text { Occasionally apprehensive }\end{array}$} \\
\hline & Present / Non-past & \\
\hline \multirow[b]{2}{*}{ Irrealis } & $\begin{array}{l}\text { Past } \\
\text { Past irrealis }\end{array}$ & Counterfactual \\
\hline & $\begin{array}{l}\text { Present / Non-Past } \\
\text { Present / Non-past irrealis }\end{array}$ & $\begin{array}{l}\text { Epistemic and/or } \\
\text { Deontic and/or } \\
\text { Desiderative/intentional }\end{array}$ \\
\hline Other & Other & $\begin{array}{l}\text { Future and/or } \\
\text { Deontic-2nd person (= imperative) }\end{array}$ \\
\hline
\end{tabular}

Let me first describe the basic pattern of composite mood marking as it is found in the majority of non-Pama-Nyungan languages. The four languages that deviate from this pattern, illustrated in (3) and (4), will be dealt with in more detail in Section 4.2.2, where I will argue that for some of them the mood system can actually be shown to derive historically from the basic composite pattern found in the other languages.

If we look at those languages that use a composite prefix-suffix system like the Wardaman structures in (1) and (2), they all show some variation of a more general pattern, schematized in Table 2.

The specific system of prefix-suffix combinations for each language is listed in Appendix 2, with page references to the relevant sections of the sources that should allow readers to check the analysis proposed here. The terminology used to describe modal meanings in the appendix will be explained in more detail in Section 2.2. Obviously, the various category labels used in the grammars were not taken as the primary criterion in comparing the systems to come to the generalization in Table 2. This would be a dangerous procedure in any typological survey, but especially so in the domain of mood and modality with its proliferation of partly overlapping terminological conventions. Instead, when the relevant formal compositionality in marking was found with the relevant resulting mood meanings, this was regarded as an instance of the system represented in Table 2, irrespective of the specific label used in the grammar in question.

If we look at the prefix paradigm of the composite mood system, what most languages have in common is a basic distinction between at least three broad categories of prefixes: (i) a non-modal prefix, usually labelled "realis" or "zero" (sometimes associated with the absence of any specific prefix, as in Wardaman), which is used in all non-modal meanings (basically simple statements of fact) and occasionally also for apprehensive modality (marking possible but undesirable events), (ii) a broad modal prefix, usually labelled "irrealis" or "po- 
tential", but also "subjunctive" (Gooniyandi, Worrorra), "future" (Jaminjung), or even "imperative" (Iwaidja), which is used in the majority of modal meanings, and (iii) a more specific modal prefix, which is used either for future or for imperatives. For ease of reference, the broad non-modal and modal prefixes will henceforth be referred to as realis and irrealis, the category labels which seem to be the most common ones in the grammars consulted, and which, as I will argue in the following sections, are also semantically the most appropriate ones.

A typical example is the system in Bunuba, illustrated in (5). The prefix $(g) a-/(g) i y-/ g u w$ - in (5a) is used with the majority of modalized structures, expressing counterfactuality, agent's desire/intention, or possibility, depending on its combination with various suffix categories (Rumsey 2000: 92-93). The prefix $w u-/ b u-(5 b)$, is a more restricted modal prefix that is used only with future and imperative structures (Rumsey 2000: 90-92). Structures without either of these prefixes, finally, form a third category, which express all non-modalized meanings, as in (5c) which merely asserts the occurrence of a past event.

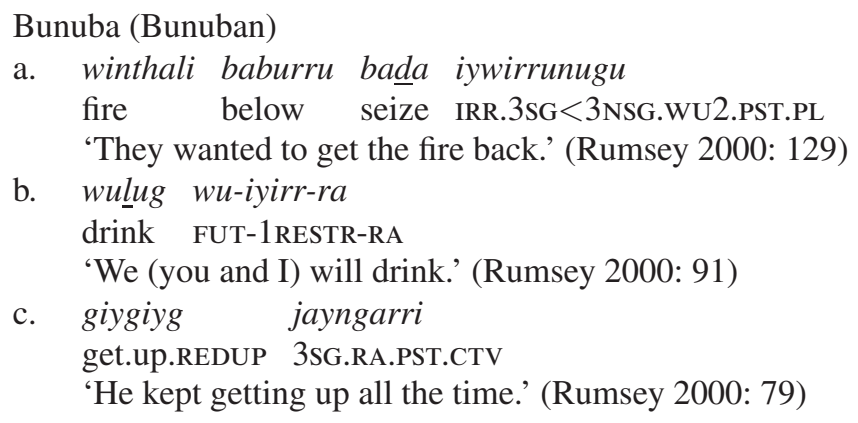

This tripartite prefix pattern is found in nineteen of the twenty-eight languages investigated: ${ }^{4}$ apart from the four languages without prefix-suffix combinations, there are also five languages which use prefix-suffix combinations but only have one or two semantically specific modal prefixes instead of the

4. As shown in the appendix, two languages from the Kimberley do not just have one broad modal prefix, but either two broad modal prefixes (Worrorra: subjunctive and irrealis) or a broad modal prefix and suffix (Gooniyandi: subjunctive and potential). In addition, the prefix and suffix in Gooniyandi are also exceptional in that they combine with prefixes following the broad modal prefix rather than with suffixes. Furthermore, in Mangarayi the markedness relations seem to be reversed in that the irrealis meanings have a zero-prefix whereas the corresponding realis forms have a full prefix, at least in the non-past. These exceptions are remarkable from a historical-comparative perspective, but they do not affect the basic semantic argument of this paper, because the systems show the same type of formal and semantic compositionality as the other languages. 
broad irrealis prefix (Bininj Gun-Wok, Maung, Ngalakan, Ngandi, and Rembarrnga). These will be discussed in more detail in Section 4.2.1, where I will show that there are good indications that such systems probably derive from a tripartite system which did have a broad irrealis prefix in contrast to a realis prefix and one or more semantically more specific modal prefixes.

As for the suffix paradigms, the languages in the sample again show a remarkable similarity, in that combinations with suffixes generally subdivide the irrealis and realis categories marked by the prefixes into several more specific categories. For the realis prefix, the relevant suffixes clearly mark categories of tense, subdividing non-modal structures into different temporal domains, usually past and present, as in the Marrithiyel structures in (6) (with - $(y) a$ for past tense in (6a) and $-\varnothing$ for present tense in (6b)), or more rarely also past and non-past as in Nunggubuyu or Mangarayi (see Appendix 2).

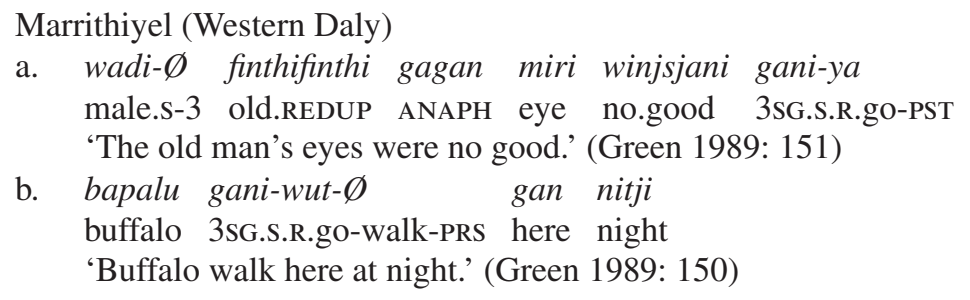

For the irrealis prefix, by contrast, the nature of the relevant suffixes is less clear at first sight, although there are good arguments in favour of an analysis as tense markers (see further also Section 2.2). One such argument is that in many languages the suffixes used with the modal prefix are formally identical to obviously temporal suffixes used in other contexts. This is the case in Marrithiyel, for instance, where past-tense - $(y) a$ is used both with the realis prefix (as in (6a)) and the irrealis prefix (as in (7a)), and present-tense - $\varnothing$ is used both with the realis prefix (as in (6b)) and the irrealis prefix (as in (7b)). In other languages, however, there is a distinct set of suffixes for use with the irrealis prefix, as is the case in Worrorra (Clendon 2000: 31-32, 64-66), which has two distinct sets of suffixes, one for use with the irrealis prefix $b a$ - (e.g., $-n$ 'present' and -nya 'past' for the verb $=n u$ ) and one for use in other contexts (e.g., $-n g(u)$ 'present' and -na 'past' for the same verb).

(7) Marrithiyel (Western Daly)

a. ngani winjsjani ngin-a fitit /

body bad 2sG.S.R.go-PST long.time /

ngun-wurr-a

1SG.S.IRR.go-die-PST

'I was sick for a long time. I could/should have died.' (Green 1989: 155) 


\section{b. warri nanggana-ya ngata gurr-puritj- $\varnothing$ \\ wet.season before-PST house 3sG.S.IRR.RR-fix-PRS \\ 'He should be fixing the house.' (Green 1989: 158)}

Semantically, there does not seem to be any prima facie evidence for a temporal function of these formally distinct suffixes in combinations with the irrealis prefix: in all of the languages with full prefix-suffix systems, the suffixes primarily serve to distinguish between counterfactuality and other types of modality rather than a distinction between temporal domains (see Table 2 and Appendix 2). As I will show in the following section, however, even in languages like Worrorra, where the suffixes used with the modal prefix are formally distinct from the basic realis tense suffixes, there are some secondary uses that form independent evidence for an association with tense.

\subsection{Semantic composition}

If we look at composite mood marking in our sample from a semantic perspective, there are two clear general tendencies in the formal system of combinations outlined in the previous section.

One tendency is that there are always at least two sets of modal meanings that use the irrealis prefix. On the one hand, the prefix always covers counterfactuality. Semantically, this is a complex type of modality that invariably has two components of meaning in the languages investigated here: potentiality and non-actualization. ${ }^{5}$ Counterfactuality signals (i) that actualization of the event described in the structure was potential, i.e., possible, desirable, imminent, or intended, but (ii) that it did not take place in spite of this desire, possibility, or intention. Thus, for instance, in Nyikina the combination of the irrealis prefix with a past suffix marks counterfactual obligation, as in (8a) where it indicates that something was desired but did not happen, or counterfactual intention, as in $(8 b)$ where it indicates that some action was intended but not carried out in the end.

Nyikina (Nyulnyulan)

a. ya-la-(rr)-DI-na-da mabu

1NSG-IRR-(NMIN)-sit-PST-HABIT good

'We should have been good (but we weren't).' (Stokes 1982: $\S 9.5 .3)$

\footnotetext{
5. Strictly speaking, the notion of "polarity reversal" would be more accurate than "nonactualization", since for negative structures counterfactuality implies actualization rather than non-actualization. Compare the English counterfactuals We should have come to the party (but did not) with We should not have come to the party (but did).
} 
b. nga-la-MA-na-dyi miliya malu nga-la-MA-na 1SG-IRR-gO-PST-EXP now NEG 1SG-IRR-go-PST 'I was going to go this morning but I didn't go.' (Stokes 1982: $\S 9.5 .3)$

In addition to counterfactuality, the irrealis prefix also covers at least one, and usually more, of the categories of deontic, epistemic, and desiderativeintentional modality. Given that these terms tend to be used with a variety of overlapping meanings in the literature (see Van der Auwera \& Plungian 1998), I will briefly explain and illustrate how I will use them here (Verstraete 2001 provides further details). Deontic and epistemic modality both mark the speaker's assessment of a situation, either in terms of the desirability of its occurrence (deontic) or in terms of the plausibility of its truth value (epistemic). The deontic type is illustrated in the Nunggubuyu structures in (9), where the irrealis prefix (labelled "class A prefix" in this language, but re-glossed as irrealis in the examples) is combined with a non-past suffix: in both cases, the structure expresses the speaker's desire that something be done.

(9) Nunggubuyu (Gunwinyguan)

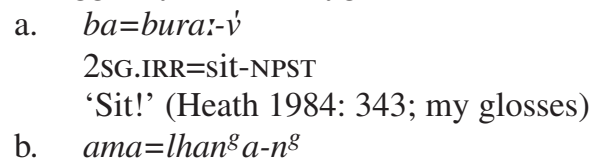

The epistemic type is illustrated from Warray in (10), where the irrealis prefix (labelled "potential" in this language) is combined with a non-complete potential suffix: in this case, the structure indicates the speaker's assessment of the plausibility of some event.

(10) Warray (Gunwinyguan)

kan-yang

POT-go.NC.POT

'He might go.' (Harvey 1986: 146)

Unlike the epistemic and deontic types, desiderative-intentional modality does not mark the speaker's assessment of a situation, but rather a clause participant's (typically an agent's) desire or intention to realize a situation. This is illustrated in the Jaminjung structure in (11), where the irrealis prefix (labelled "Potential/Future" in this language, but semantically equivalent to the other irrealis prefixes in the sample, as reflected in its range of uses outlined in Appendix 2) is used without a suffix. 


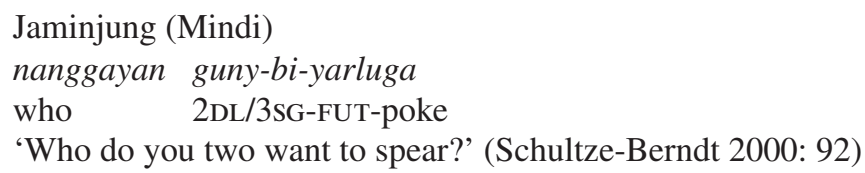

Taken together, these three types of modality can be regarded as instantiations of a more general semantic category of potentiality, projecting potential actualization of an event, either from the perspective of the speaker, who wants the event to be realized (deontic) or who thinks realization is plausible (epistemic), or from the perspective of a clause participant, who intends to realize the event (desiderative-intentional).

The second general semantic tendency found across the languages with a composite system is that, within the set of senses covered by the irrealis prefix, the counterfactual sense is invariably distinguished from the potential senses (epistemic, deontic, and desiderative-intentional) by means of combination with different suffixes. As already mentioned in the previous section, in many languages these suffixes are identical to the tense suffixes that are used with the realis prefix, but in others they have distinct forms. Even for those suffixes that are distinct, however, there is some independent evidence for an association with tense: apart from their use in modal structures, the distinct suffixes also tend to be used in constructions that contain specific negative markers, and in these constructions there is clear evidence for a basic temporal function. This is the case, for instance, in Worrorra, which uses its distinct set of irrealis tense suffixes (exemplified in Section 2.1 above) not only for various types of modality, but also in negative constructions, as shown in (12). In these negative constructions the two suffixes are semantically distinguishable only in terms of a feature of tense - present for (12a) and past for (12b) - which provides independent evidence that they are tense-related, and suggests that they could be regarded as the specialized "irrealis" counterpart of the basic tense suffixes used in constructions without the irrealis prefix. Section 4.2.1. will provide an explicit diachronic scenario for the development of such specialized "irrealis" tense suffixes.

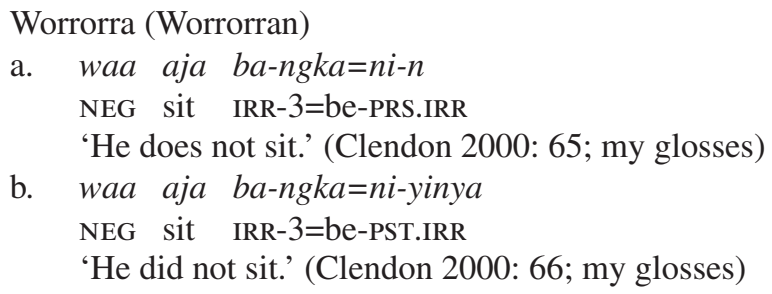




\subsection{Counterfactuality: The central problem}

If we try to analyse these basic semantic tendencies in a way that reflects the formal compositionality of the system outlined in Section 2.1, the crux is obviously how to deal with the counterfactual uses. Formally, these uses are marked by a combination of an irrealis prefix that has epistemic, deontic, and/or desiderative-intentional uses in other contexts, and a suffix that in most languages has past-tense functions in other contexts. If we apply the principle of semantic compositionality, therefore, what we would expect for such combinations is a meaning of past epistemic, deontic, and/or desiderative-intentional modality. While there is some evidence for the presence of this aspect of meaning in counterfactual utterances, in the sense that they express non-actualization IN SPITE OF some desire, possibility, or intention, as shown in the previous section, the crucial feature of non-actualization that defines counterfactuality and distinguishes it from other types of modality does not easily fit into this compositional account.

From a more general perspective, the problem posed by the description of counterfactual structures in non-Pama-Nyungan languages is also at the heart of the problem of defining irrealis as a semantic category in the description of modality. As noted in other crosslinguistic studies of modality like Mithun (1995) and Elliott (2000), there seem to be two different ways in which irreality can be instantiated, often marked by one and the same formal category of irrealis but not so easily reconciled in semantic terms. On the one hand, there is the notion of potential actualization of an event, which in the context of the nonPama-Nyungan system seems to be an adequate generalization for the epistemic, deontic, and desiderative-intentional uses, while on the other hand there is the notion of non-actualization of an event, which in the non-Pama-Nyungan system can be associated with the counterfactual uses. For some authors, like Bybee, Perkins, \& Pagliuca (1994) and Bybee (1998), the semantic divergence of irrealis categories has been used along with other arguments to dismiss the validity of irreality as a modal notion. In the following sections, I will try to show on the basis of the non-Pama-Nyungan data that this apparent divergence of features should not be seen as an argument against the validity of irreality, and that there is good evidence that the two features can be linked.

\section{The nature of counterfactuality}

\subsection{Counterfactuality as an implicature of past potentiality}

The fact that counterfactuality is distinguished from other types of modality in the composite mood system by means of a combination with past tense should come as no surprise. The feature of past tense figures prominently in most studies of counterfactuality, which have long recognized that this seems 
to be a crosslinguistically recurrent element of counterfactuality marking (see, e.g., James 1982 and Fleischman 1989). In one popular theory, the link between past tense and counterfactuality is explained in terms of a metaphorical relation between the two domains, with distance in time serving as a model for distance in reality (Fleischman 1989). Past and non-reality are functionally similar, it is argued, in that both involve distance from the here-and-now, in one case distance in the domain of tense, in the other distance in the domain of reality. Because of this functional similarity, past tense and non-reality will often share patterns of formal marking: past-tense markers will not only have their basic function of marking past temporal reference, but will typically also be extended to constructions that involve non-reality, like counterfactual ones. As pointed out by Dahl (1997), however, a major problem with this hypothesis is that past tense never marks counterfactuality on its own: when used in counterfactual contexts, it is almost invariably accompanied by another type of marker, typically with some modal flavour, either a purely modal one like the irrealis prefix in the non-Pama-Nyungan languages examined here, or a modal conjunction like a conditional marker. This distributional restriction shows that distance in time is certainly not the only feature to be taken into account in explaining the role of past tense in counterfactual marking, and that the metaphor theory is not tenable. Instead, an adequate account of the relation between past tense and counterfactuality should also take into account its association with modal expressions that mark some kind of potentiality.

As an alternative, I would like to propose that the combination of features of potential modality and past tense, as found in the prefix-suffix combinations in the sample investigated here, is pragmatically marked vis-à-vis the default non-modal past structure, and that it is this pragmatic markedness that typically triggers counterfactuality implicatures. The starting point of this proposal is the work of Ziegeler (2000), who in her account of the diachrony of conditional constructions in English, suggests that conditional clauses ("if p") and modalized expressions ("possible p") form a scale of informativeness with the corresponding non-modalized expression ("p"). Just like the classic quantifier example with some and all (Horn 1989), use of the weaker expression on the scale ("if p" or "possible p", compare some) implicates the negative of the stronger expression ("not p", compare not all) by the first Gricean maxim of quantity ("make your contribution as informative as is required", Grice 1975: 45). When dealing with propositions rather than quantifiers, negation of the non-modalized counterpart of a proposition amounts to non-actualization, and therefore to counterfactuality: using "it was possible that p" rather than the more informative "p happened" conversationally implicates that $p$ did not happen. Although this analysis does not yet explain the role of past tense, I do think it identifies the basic pragmatic mechanism underlying counterfactuality: modal expressions of potentiality are weaker on a scale of informativeness than 
their non-modalized counterparts, and this is what triggers the implicature of non-actualization that leads to counterfactuality.

What is further needed to explain the privileged role of past tense, however, is a better understanding of the NATURE of the scale between modalized and non-modalized expressions. In general, I would not draw a strong analogy between the case of counterfactuality and the traditional case of quantifiers like some and all, if only because with modal expressions there are no logical relations of inclusion to check scalarity relations. Instead, I believe the basis of the scale can best be described in rhetorical rather than truth-functional terms, based on the notion of epistemic strength: a past modalized expression like " $p$ was possible, desirable, or intended" is epistemically weaker than its non-modalized counterpart "p happened" because it involves a judgement of potentiality rather than certainty. Using the epistemically weaker expression of potentiality will trigger the implicature that there was a reason not to use the stronger non-modal expression, i.e., that the event did not take place. Crucially, this concept of epistemic strength can explain the privileged position of past tense in counterfactuality constructions. Because the past is inherently knowable, a past non-modal expression will be an expression of certainty, and will therefore be epistemically stronger than its counterpart of potentiality, and will trigger implicatures of non-actualization. This is no longer the case if we move from the past to the non-past domain, which is also the reason why future expressions of potentiality like " $p$ is possible, desirable, or intended" do not implicate that "p will not happen".

As noted by one reviewer, it may actually be necessary to distinguish the present from the future within the non-past domain, because in theory the present is knowable just like the past, and should trigger the same counterfactuality implicatures. If we look at the sample, there is in fact one language that confirms this prediction: in Marrithiyel, a combination of an irrealis prefix with a present suffix creates a deontic meaning that is distinct from other deontic meanings (marked by irrealis-future combinations) in that the actions referred to are socially expected or obliged but "not currently being carried out" (Green 1989: 158), as illustrated in (13).

$$
\begin{aligned}
& \text { Marrithiyel (Western Daly) } \\
& \text { wudi firrinjinggi-purrngpurrng-nginel-fini- } \emptyset \\
& \text { water 3NSG.S.IRR.NJ-boil-1sG.PURP-DL-PRS } \\
& \text { 'They should be boiling water for me.' (Green 1989: 158) }
\end{aligned}
$$

In addition to this possibility, another strategy that is probably more common crosslinguistically is for a language to extend its past-tense counterfactuals to include structures with present-tense reference. In our sample, this strategy is found in Bininj Gun-Wok, where the basic irrealis construction used for past 
counterfactuality can also be used to denote counterfactuality with presenttense reference: compare (14a), which illustrates the standard counterfactual, with past-tense reference, with (14b), which illustrates a counterfactual with present-tense reference (in this case a present non-actualized desire).

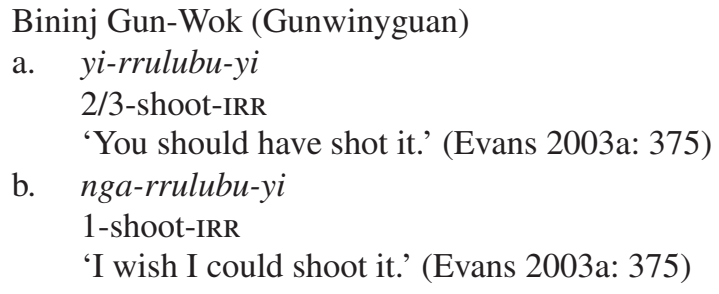

Whatever the strategy used, however, in either case the formal marking used for counterfactuals that refer to events in the present combines a modal element with a tense element from a "knowable" domain, and thus conforms to the basic explanation in terms of an implicature deriving from a clash between a modal element that encodes potentiality and a tense element that implies certainty.

In conclusion, therefore, in general pragmatic terms it is plausible to analyse the association between counterfactuality and past modality as a Gricean implicature mechanism triggered by the pragmatically marked combination of past tense and modality. Unlike other theories of counterfactuality, this analysis takes into account both the association with past (or, occasionally, present) tense and the association with modal markers that express potentiality: the modal feature of potentiality is needed to create a scalar relation with the corresponding non-modal expression of certainty, and the past feature whose corresponding non-modal expression marks certainty and thus gives an epistemic maximum relative to which the modal expression triggers an implicature of non-actualization.

\subsection{Further arguments for the origin in an implicature}

An analysis of counterfactuality as originating in an implicature from the combination of past tense and potentiality is not only plausible in general pragmatic terms, but it also helps to make sense of a number of otherwise inexplicable characteristics of counterfactual expressions in non-Pama-Nyungan languages (and beyond).

Apart from the fact that it takes the formal compositionality of the system seriously, a further argument in favour of the proposed analysis is that it also explains the semantically complex nature of counterfactuality, a characteristic that is commented on surprisingly rarely in the literature. As already mentioned in Section 2.2, counterfactual expressions never merely indicate that something did not take place - after all, languages have negative markers to 
do this job. Instead, they combine the component of non-actualization with a modal component that expresses some kind of potentiality: something was possible, desirable, or intended, but in the end it did not take place, in spite of this potentiality. In the proposed analysis, the emphasis on the contribution of the modal element to the counterfactual implicature can also do justice to this aspect of counterfactual expressions: the component of potentiality is part of the basic meaning, adduced by the irrealis prefix, and the implicature of nonactualization does not replace it but is simply added onto it. In this perspective, it is not surprising at all that the component of potentiality in the counterfactual structures marked by the irrealis prefix in combination with a past suffix simply duplicates the set of modal meanings found in the combinations of the same prefix with a non-past suffix. As argued above (see Table 2), a combination of the irrealis prefix with a non-past suffix generally covers one or more of the deontic, epistemic, and desiderative-intentional types of modality. Significantly, the same three categories are also found as components in the semantics of counterfactual expressions, which combine the same irrealis prefix with a past suffix. Thus, there is deontic counterfactuality, which marks non-occurrence in spite of past desirability, as illustrated from Limilngan (15). There is also epistemic counterfactuality, which marks non-occurrence in spite of past possibility, as illustrated from Gooniyandi (16). And there is desiderative-intentional counterfactuality, which marks non-occurrence in spite of some participant's intention or desire, as illustrated from Wagiman (17).

$$
\begin{aligned}
& \text { Limilngan (Limilngan) } \\
& i \text { da-wi-k wulun i-rr-a-wi-rri } \\
& \text { yes DEF-I-DIST other 3>I-IRR-hit-PST }
\end{aligned}
$$

'He should have hit that other bloke.' (Harvey 2001: 96)

(16) Gooniyandi (Bunuban)

$$
\begin{array}{lll}
\text { yoowooloo-ngga } & \text { marni-wa } & \text { gard-ja-yooni } \\
\text { man-ERG } & \text { sister-his } & \text { hit-SUBJ-IRR+BINI }
\end{array}
$$

'The man might have hit his sister (though I know he didn't).' (McGregor 1990: 548)

(17) Wagiman (Yangmanic)

$\begin{array}{lllll}\text { gornkorn nga-ngaha-ny } & \text { nung gahan jilimakgu // } \\ \text { talk.PFV IRR-1SG.say-PST.PFV } & \text { 3sG.OBL that woman // } \\ \text { nga-ngotjijeji-na } & & & \end{array}$

1sG-be.afraid-PST

'I wanted to say something to that woman, but I was too scared.' (Wilson 1999: 31)

This variety of modal features is not only found across the sample of languages: even within one language it is usually the case that the counterfactual 
construction can have more than one type of modality in its meaning, as becomes clear from a cursory glance at the tables in Appendix 2. In conclusion, therefore, the presence of a component of potentiality in addition to the component of non-actualization, as well as the variety of types of potentiality found in this component, can only be explained in an analysis which takes into account the contribution of both basic building blocks of past tense and potentiality in the final counterfactual interpretation.

A final argument in favour of the proposal that the feature of non-actualization originates in an implicature of past potentiality is that this feature can actually be cancelled in some instances, with only the meaning of past potentiality remaining, which shows that in these instances non-actualization synchronically still functions as an implicature. The prefix-suffix combinations investigated here most typically have counterfactual meanings, and are usually described and labelled as such in the reference grammars, but there are also some examples where the same prefix-suffix combination only has a past potential meaning without non-actualization. This is not often commented on in the sources used, so it is impossible to provide a systematic treatment of this phenomenon, but there are some telling instances which show that nonactualization is not intended. In her description of Jaminjung, for instance, Schultze-Berndt (2000) notes that "the pragmatic inference arising from the use of [the relevant counterfactual combination, i.e., a future prefix combined with an imperfective suffix; JCV] is usually that the event in question was not realized" (2000: 92), as in (18) where the past intention to make damper is not carried out.

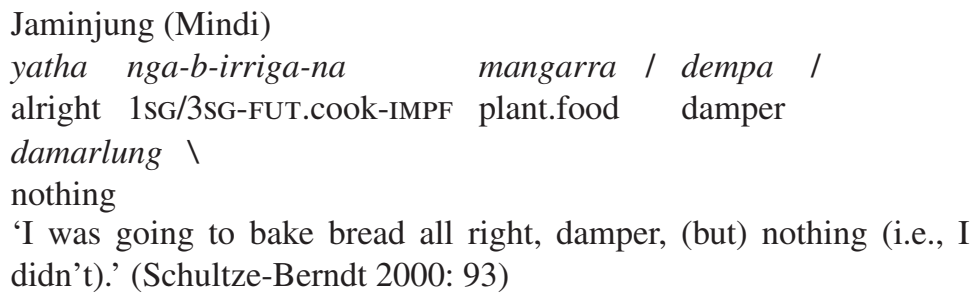

She also shows, however, that the same prefix-suffix combination can equally occur with a past potential meaning without a component of non-actualization, as in (19) where there is a clear contextual indication that the event of "finding a camp" is eventually actualized (the speaker found a camp at Gurlugurlu), and where the prefix-suffix combination simply expresses the agent's past intention. 


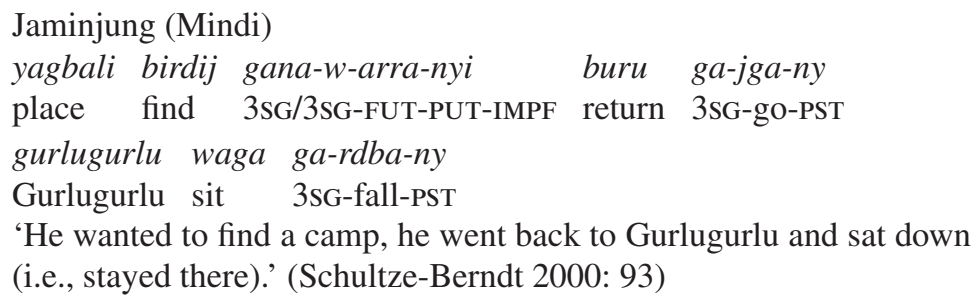

There are other instances where non-actualization does not seem to be central in the interpretation of a structure that otherwise has a default counterfactual interpretation. The Bunuba combination of irrealis prefix and past suffix exemplified in (5a) above, for instance, usually has an interpretation that includes non-actualization of the event described. For the particular example in (5a), however, further context (Rumsey 2000: 129-130) shows that the desired event is in fact realized in the end, i.e., that the people get the fire back, which suggests that the structure basically encodes the agent's past desire without the feature of non-actualization.

The same variation between past modal interpretations with and without a component of non-actualization is also found in some types of complex sentence constructions, where it is probably more systematic (see Verstraete forthcoming for more detailed discussion). In Rembarrnga, for instance, past counterfactual mood typically has a counterfactual interpretation, both in simple clauses like (20a) where it indicates that the speaker did not go hunting in spite of his intention to do so, and in complex sentences like the conditional structure in (20b) where it indicates that the speaker did not miss the buffalo and consequently did not hit the people.

$$
\begin{aligned}
& \text { Rembarrnga (Gunwinyguan) } \\
& \text { a. kuwa ya-tal-mə karə? pulut-tə } \\
& \text { PURP 1MIN.S-go.hunting-PST.CF but bullet-PRIV } \\
& \text { 'I was going to go hunting, but I have got no bullet.' (McKay } \\
& \text { 1975: 244) } \\
& \text { b. நanapparu- } \varnothing \text { ii-pețetka-pə matţi? } \\
& \text { buffalo-NOM 3MIN.O+1MIN.A+REL-miss-PST.CF but } \\
& \text { pi-Ø paya-mə?-kur?war-mə-kappul } \\
& \text { person-NOM 3AUG.O+1MIN.A-lest-shoot-PST.CF-DEFAUGM } \\
& \text { 'But if I had missed the buffalo I might have hit the people.' } \\
& \text { (McKay 1975: 331) }
\end{aligned}
$$

There is one type of complex sentence, however, where the component of non-actualization can be dropped: in the past purpose construction in (21), there is no indication that the event of spearing marked with past counterfactual mood did not take place, and as noted by McKay (1975: 320-321) the 
following context shows that the man was actually speared, ${ }^{6}$ as intended by the agent of the main clause. What is relevant in this construction is again just a meaning of past potentiality without a component of non-actualization: in this case, the mood marker in question marks the intention to spear the man (i.e., a component of desiderative-intentional modality) from the past-tense perspective of the agent of the action described in the main clause (i.e., a component of past tense).

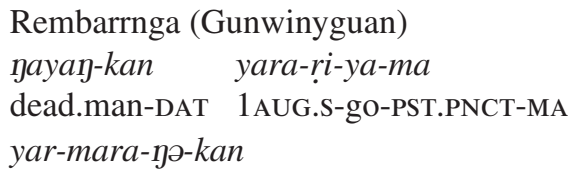

In combination with the previous arguments, the occasional variability of the feature of non-actualization is another argument in favour of an analysis of counterfactuality as originating in an implicature of a more basic meaning of past potentiality. Whereas the other arguments focused on the presence of past-tense and potentiality components in the final interpretation of counterfactual expressions, this argument focuses on the component of non-actualization as such. If this component really originates as an implicature, then it should still be cancellable in some cases, with structures that only have a past modal meaning without an implicature of non-actualization, like the examples in (5a), (19), and (21).

It is important to note, however, that the argument about cancellability cannot be reversed: cancellability need not be found in every language in the sample. The argument presented above is essentially an argument about origins: it is well-known that generalized implicatures of the type discussed here tend to be semanticized in some languages, and can then become inherently associated with a particular construction type rather than a typical but cancellable feature. This is a process that has been documented in detail by Traugott \& Dasher (2001) for various other types of modal meanings across different languages, so it would not be unusual to find the same process operating here. In a language like Gooniyandi (McGregor 1990, personal communication), for instance, it is not possible to use the counterfactual construction marked by a combination of

6. On the basis of the absence of a counterfactual component, McKay (1975: 321-322) suggests that the past counterfactual marker could be reanalysed as the homophonous infinitive marker, in spite of the presence of person agreement markers which he otherwhise uses to distinguish past counterfactual mood from the infinitive. Apart from the arguments presented here, further arguments against such a reanalysis are presented in Verstraete (forthcoming). 
potential and irrealis to simply refer to past potentiality without the feature of non-actualization, which means that counterfactuality is no longer cancellable for this construction. Instances like this do not invalidate the implicature analysis, because variable semanticization of a feature in different languages is exactly what one would expect if it originates as an implicature. What is more, the other types of evidence outlined in this section remain relevant even in those cases where the feature of non-actualization is no longer cancellable. Thus, counterfactual structures in Gooniyandi are still semantically complex, because they show features of past epistemic, deontic, and even desiderativeintentional modality in addition to the feature of non-actualization, as seen in (22) which combines past deontic modality with non-actualization.

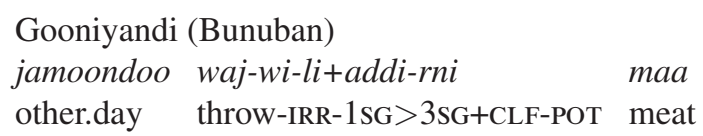

Even if variable semanticization is not an argument against the implicature analysis, it is an interesting question for further research if there is any tendency as to which uses tend to semanticize non-actualization. One reviewer notes that all instances of cancellable non-actualization cited here are related to desiderative-intentional types of potentiality. This may suggest a possible semantic motivation, but in the absence of detailed descriptions of the phenomenon for many languages, such links cannot be investigated in sufficient detail.

\section{Composite mood marking: A unified perspective}

In this section, I will use the analysis developed in the previous sections to present a unified model of composite mood marking in the non-Pama-Nyungan languages, integrating both the semantically deviant patterns, particularly the counterfactual constructions (Section 4.1), and the formally deviant patterns, especially those languages that seem to lack the broad modal prefix found in the majority of languages (Section 4.2.1) and those languages that use nonverbal auxiliaries instead of prefix-suffix combinations to the verb (Section 4.2.2).

\subsection{Problems with semantic compositionality}

As argued in Section 2, the semantic crux of the systems of composite mood marking described here is the nature of counterfactuality, and the question of how counterfactual constructions can be integrated into the basic semantic organization of the system. To recapitulate briefly, the system can be analysed 
Table 3. Formal and semantic features in the system

\begin{tabular}{|c|c|c|}
\hline \multicolumn{2}{|c|}{ Form } & \multirow{2}{*}{ Meaning } \\
\hline Prefix & Suffix & \\
\hline \multirow[b]{2}{*}{ Irrealis } & Non-past & $\begin{array}{l}\text { Non-past } \\
\text { Potential } \\
=\text { epistemic, deontic, desiderative-intentional }\end{array}$ \\
\hline & Past & $\begin{array}{l}\text { Past } \\
\text { Potential } \\
\text { Non-actualization } \\
=\text { counterfactual }\end{array}$ \\
\hline
\end{tabular}

into a number of basic formal components (an irrealis prefix and a paradigm of two suffixes) and a number of basic semantic features (potentiality, nonactualization, and tense), mapped onto each other as in Table 3.

There is an obvious compositional organization in the system, with potentiality associated with the irrealis prefix and tense associated with the suffix paradigm as shown in Section 2.2, but the feature of non-actualization found in the counterfactual uses is hard to integrate into this compositional organization. It cannot be assigned to the prefix, because there are uses of the prefix that merely encode potential actualization without non-actualization (the basic epistemic, deontic, and desiderative-intentional uses), and it cannot be associated with the suffix paradigm, because there are uses of the suffix paradigm that merely encode tense without non-actualization (in combination with the realis prefix). ${ }^{7}$ The obvious solution is to associate non-actualization with a particular combination of prefixes and suffixes rather than an individual prefix or suffix paradigm, and the previous section has shown how this association can be motivated in functional terms, as an outgrowth of a combination of past and potentiality driven by general pragmatic principles. This solution takes the semantic complexity of counterfactual structures into account, and at the same time allows one to reconcile the feature of past potentiality, which accords with the basic compositional make-up of the system, with the feature of non-actualization, which seems to be outside the formal organization of the system.

\subsection{Problems with formal compositionality}

Apart from the semantic problem of counterfactuality, another problem identified in Section 2 was the existence of a number of non-Pama-Nyungan lan-

7. For those languages that have a distinct set of suffixes to be used with the irrealis prefix, these suffixes may actually combine tense with a feature of non-actualization, but this can probably be analysed as a secondary diachronic development, as I will show in Section 4.2.1. 
guages that formally deviate from the basic pattern of composite mood marking described so far. Broadly speaking, there are three types of formal variation on the basic prefix-suffix pattern. First of all, there are languages like Kayardild and Mara, which are exceptional among the non-Pama-Nyungan languages in that they do not use prefixes at all, but only have a suffix system for mood marking on the verb. Secondly, there are languages like Wambaya and Yukulta, which use verbal suffixes in combination with a separate, synchronically non-verbal, clitic complex to mark mood categories. Finally, there are also languages like Bininj Gun-Wok, Maung, Rembarrnga, Ngalakan, and Ngandi, which use combinations of prefixes and suffixes, but at most have a semantically restricted modal prefix (used for future or apprehensive modality) rather than the broad irrealis prefix found in the languages investigated so far. In this section, I will investigate how the latter two of these formally deviant systems may relate to the basic prefix-suffix pattern. More specifically, I will argue that some of the systems appear to be diachronically related to the basic prefix-suffix pattern as outlined in Table 2 above, and I will sketch a number of diachronic scenarios of how the change from composite to non-composite mood marking may have occurred. These scenarios also include a possible explanation for the existence of specialized suffixes that combine tense and mood information, as distinct from the tense suffixes found with the basic realis prefix.

4.2.1. Languages with restricted prefix systems. Bininj Gun-Wok, Maung, Rembarrnga, Ngalakan, and Ngandi are five non-Pama-Nyungan languages that deviate from the general prefix-suffix pattern in that they do not have the broad modal prefix identified in the languages studied so far. Still, they are genetically related to other languages that do have a general realis-irrealis distinction in their prefix system, in addition to one or two more specialized modal prefixes: Maung, for instance, is related to Iwaidja (Evans 2000), and Bininj Gun-Wok, Rembarrnga, Ngalakan, and Ngandi are related to other Gunwinyguan languages like Nunggubuyu, Warray, and possibly also Mangarayi (Evans 2003b). This genetic relatedness suggests that there may be some diachronic relation between the restricted and the full prefix-suffix systems, either with the restricted system as a remnant of the full one, or the full system as an innovation building on the restricted one.

Apart from the genetic relatedness to languages with full prefix-suffix systems, there are also a number of structural features that indicate a diachronic relation of the restricted systems in Bininj Gun-Wok, Maung, Rembarrnga, Ngalakan, and Ngandi to the full systems investigated in the previous sections. First of all, it can be noted that four of the five languages make a systematic distinction between realis and irrealis tenses within the tense categories of the suffix system. Thus, in Rembarrnga there is no irrealis prefix, but there is a 
distinction between a realis past tense and an irrealis one, labelled past counterfactual in McKay (1975) and used in counterfactual and past negative contexts. Similarly, Maung (Singer 2003) has three realis tense suffixes and two irrealis tense suffixes, one of which is used predominantly in past contexts like counterfactual and past negative and the other in nonpast contexts like epistemic, present negative, and future negative. Ngandi also has two realis past tenses (past punctual and past continuous) and one irrealis one (labelled "potential") which is used predominantly ${ }^{8}$ in contexts like counterfactuality. Bininj GunWok, finally, has two realis past tense suffixes and one irrealis one, ${ }^{9}$ which is used mainly in past negative and past counterfactual contexts, and can also be extended to present counterfactual contexts as shown in Section 3.1 above.

This type of system is in fact functionally equivalent to the composite system, in which the irrealis prefix contributes the feature of potentiality and the suffixes contribute the features of tense. The difference is that in the restricted systems, the tense suffixes incorporate the basic distinction between reality and potentiality in the form of a separate set of past (and/or nonpast) suffixes that mark the same modal categories as the ones that are covered by the irrealis prefix in the composite system. Significantly, the same modal specialization in the tense suffixes can also be found in some of the languages that have the full prefix-suffix system: some languages, like Wagiman, Nunggubuyu, or Wardaman, have the same tense suffixes for the realis and irrealis prefixes, whereas others, like Nakkara, Ndjébbana, or Ungarinjin, have distinct realis and irrealis tense suffixes for the realis and irrealis prefixes. In combination, this gives us three types of functionally equivalent mood systems, each of which is attested in the set of languages investigated: (i) a basic realis-irrealis distinction in the prefixes, with one set of tense suffixes that are shared between the realis and the irrealis prefixes, (ii) a basic realis-irrealis distinction in the prefixes, with separate sets of tense suffixes for the realis and the irrealis prefixes, and (iii) no realis-irrealis distinction in the prefixes, with separate realis and irrealis tense suffixes. The three types are schematically represented in Table 4, with NPST standing for any non-past tense category, either present or future.

Given that the languages of type 3 are genetically related to languages of types 1 and 2, the three types could perhaps be regarded as three stages in the diachronic development of mood marking, with type 2 as an intermediate type between the full prefix-suffix system investigated in the first sections of this

8. There is also a rare use in present deontic contexts, as noted in Heath (1978: 106).

9. The basic past-tense nature of these three suffixes is further confirmed by the rather unusual merging of pronominal prefixes with tense rather than mood, a feature that sets Bininj GunWok apart from all other languages in the sample. The 3rd person pronominal prefixes show a distinction between a past and a non-past series, and both the irrealis suffix and the two past realis ones are exclusively combined with the past series rather than the non-past one. 
Table 4. Functionally equivalent systems in the data

\begin{tabular}{|c|c|c|c|c|}
\hline \multicolumn{2}{|c|}{$\begin{array}{l}\text { Type } 1 \\
\text { R-IRR prefixes \& same } \\
\text { tense for R \& IRR }\end{array}$} & \multicolumn{2}{|c|}{$\begin{array}{l}\text { Type } 2 \\
\text { R-IRR prefixes \& differ- } \\
\text { ent tense for IRR }\end{array}$} & $\begin{array}{l}\text { Type } 3 \\
\text { Absence of R-IRR pre- } \\
\text { fixes \& different tense } \\
\text { for IRR }\end{array}$ \\
\hline \multirow{2}{*}{$\mathrm{R}$} & PST & \multirow{2}{*}{$\mathrm{R}$} & PST & PST \\
\hline & NPST & & NPST & PRS \\
\hline \multirow{2}{*}{ IRR } & PST & \multirow{2}{*}{ IRR } & PST IRR & PST IRR \\
\hline & NPST & & NPST IRR & NPST IRR \\
\hline
\end{tabular}

study and the restricted system found in Bininj Gun-Wok, Maung, Rembarrnga, Ngalakan, and Ngandi. In this scenario, semantic specialization in the suffix system duplicates mood information from the prefix system, and becomes the only locus of mood marking when mood marking formally disappears in the prefix system.

The structural features of the mood systems as such do not provide any clues about directionality in this scenario, but there is some evidence of earlier irrealis-type prefixes in languages of type 3, which may point towards a development going from the composite type one to the non-composite type 3 . In Rembarrnga, for instance, there is a generalized subordinate marker in the prefix system (fused with bound pronoun prefixes, i.e., marked with a separate series of bound pronouns, McKay 1975), which could be interpreted as a remnant of an earlier irrealis prefix. An interpretation as a remnant of an earlier irrealis prefix for this type of subordinate marker is not implausible, given that (i) generalized subordinate markers in other non-Pama-Nyungan languages are usually verbal suffixes rather prefixes, as in Bunuba (Rumsey 2000), Ngalakan (Merlan 1981), Nyikina (Stokes 1982), Wardaman (Merlan 1994), or Warrwa (McGregor 1994), and (ii) when such subordinate markers belong to the prefix series they also function as irrealis markers, as in Mangarayi (Merlan 1981, 1982).

This is of course merely a hypothetical scenario, which requires testing with extensive historical-comparative work on the actual forms used in the verbal system of the languages in question, a task that obviously goes beyond the objectives of this study. The central argument in this section was simply to point out how the specialization of tense suffixes to tense/mood suffixes in the restricted systems can be functionally related to the role of tense in the full systems in genetically related languages, and to sketch a possible scenario for change from a composite system to a non-composite one.

4.2.2. A separate non-verbal auxiliary. A second type of deviation from the basic prefix-suffix system is found in Yukulta and Wambaya, where mood 
is marked by a combination of modal suffixes to the verb root and a modal element within a separate non-verbal auxiliary element that otherwise also contains bound pronouns. In this section, I will only deal with Wambaya, for which I will argue that the modal component of the non-verbal auxiliary element can be analysed as a "condensed" version of the basic prefix-suffix system as discussed in the previous section. This suggests that the synchronically non-verbal auxiliary historically derives from a verb with prefixes and suffixes (as also argued in another context by Green (1995), Nordlinger (2001), and Green \& Nordlinger (2004)), a hypothesis that is independently confirmed by other features of this auxiliary element.

The Wambaya system is illustrated in (23), partly repeated from Section 2 above. As already mentioned, mood marking is spread over two places: the verb, which shows a contrast between suffixes labelled future (23a, b) and non-future (23c), and the auxiliary element, which shows a contrast between categories labelled future (23b), non-future (23a), past non-actual (23c), and present non-actual mood.

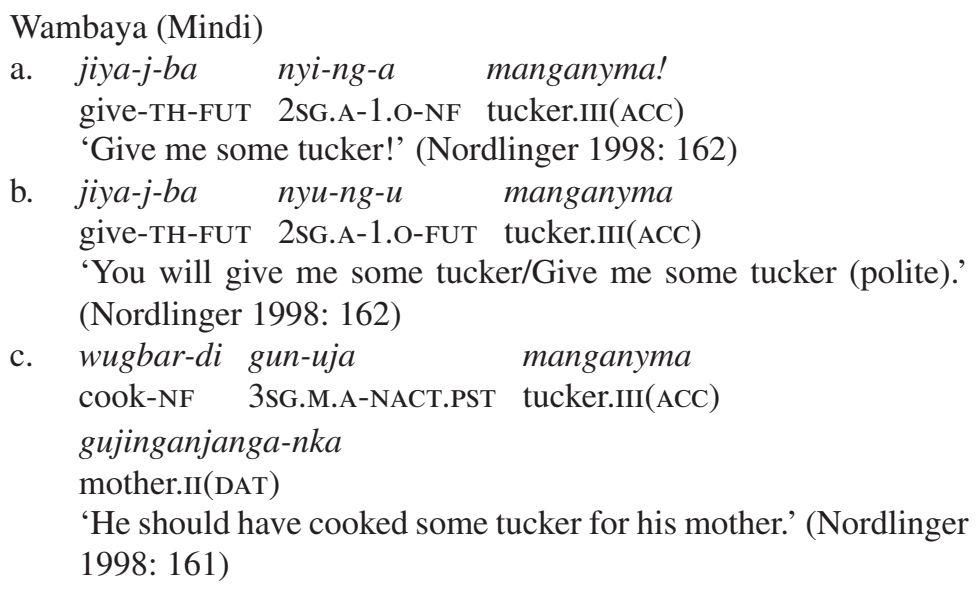

If we look at the types of mood meaning that are expressed by these markers, there is a striking semantic resemblance between the future/non-actual past/non-actual present paradigm in the Wambaya auxiliary element and the prefix-suffix combinations discussed in the previous sections. Non-actual past and non-actual present mark counterfactuality, negative past, and negative present, always in combination with a non-future suffix to the verb. Future marks future tense, a polite version of deontic modality, and negative future, the latter only in combination with a non-future suffix on the verb. Taken together, this set of meanings closely corresponds to the set of meanings that is generally covered by a broad irrealis prefix in combination with different tense suffixes: counterfactual and past negative in combination with past, and deontic, future, 
Table 5. Mood in the Wambaya auxiliary as a composite system

\begin{tabular}{|l|l|l|}
\hline Element 1 & Element 2 & Modal meaning \\
\hline \multirow{3}{*}{ Irrealis: $-u$} & Past: $-d a /-j a$ & $\begin{array}{l}\text { Counterfactual } \\
\text { Past negative }\end{array}$ \\
\cline { 2 - 3 } & Present: $-d i /-j i$ & Present negative \\
\cline { 2 - 3 } & Future: $\varnothing$ & $\begin{array}{l}\text { Future } \\
\text { Future negative } \\
\text { Deontic (2) }\end{array}$ \\
\hline
\end{tabular}

future negative, and present negative in combination with various non-past suffixes.

If we look more closely at the formal expression of the three categories in the Wambaya paradigm, it is clear that the correspondence is not just in the semantics of the system. Future is expressed by $-u$, non-actual present is expressed by $-u d i /-u j i$, and non-actual past is expressed by -uda/-uja: in this series, it is possible to isolate an element $-u$ - in this paradigm, with $\emptyset,-d i /-j i$ and $-d a /-j a$ increments, as suggested but not implemented by Nordlinger (1998: 149-150). Formally therefore, the Wambaya system can equally be analysed as a composite system, with the $-u$-element corresponding to a generalized irrealis prefix, and the $\emptyset,-d i /-j i$, and $-d a /-j a$ elements corresponding to the tense suffixes that mark specific subdomains of irrealis. Table 5 schematically presents this analysis, which brings out the parallellism with the prefix-suffix combinations in the composite systems.

Although the auxiliary element is synchronically non-verbal in Wambaya, the strong structural similarity of its modal component to the verbal systems investigated in the previous sections suggests that this element may have a diachronic origin as a finite verb with agreement and mood marking in the prefix system and tense marking in the suffix system, which at some stage lost its verbal character. This analysis is in fact confirmed by independent evidence from other characteristics of the auxiliary element, as described in Nordlinger (2001). On the one hand, Nordlinger argues that the bound pronouns and tenseaspect-mood marking that make up the auxiliary is the same set of elements (in the same order) as the affixes on finite verbs in related non-Pama-Nyungan languages, an argument that can now be expanded with an internal analysis of the mood markers, as shown above. Secondly, she also notes that the auxiliary in some exceptional cases can be used as the sole predicate of the clause (Nordlinger 2001: 404), which further supports a diachronic origin as a finite verbal element. Finally, Nordlinger (2001) also shows that the auxiliary element is not completely semantically empty apart from its pronominal and TAM marking, but that there are some other categories like direction markers which 
can be regarded as remnants of an earlier verbal element and are also used as such, for instance in associated motion constructions like (24).

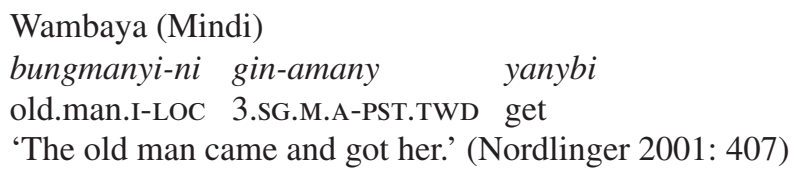

In conclusion, the formally deviant system of mood marking in Wambaya can equally be reduced to the basic prefix-suffix pattern as found in the majority of the non-Pama-Nyungan languages. The mood markers in the auxiliary element internally show the same compositionality as found in the other languages, and there is independent evidence to show that the auxiliary element as a whole is diachronically related to a finite verb construction with prefixes and suffixes.

\subsection{A unified analysis}

Table 6 summarizes the unified analysis of composite mood marking proposed here. The three rows present the basic composite system and its formal variations. The middle row represents the basic system, with a broad irrealis prefix, and tense suffixes that are either identical for realis and irrealis (on the left), or distinct (on the right). The bottom row represents the restricted composite system, which does not have a broad irrealis prefix but which has separate tense

Table 6. A unified analysis of composite mood marking

\begin{tabular}{|c|c|c|c|c|c|}
\hline & \multicolumn{4}{|l|}{ Form } & \multirow[t]{2}{*}{ Function } \\
\hline & Prefix & Verb & \multicolumn{2}{|l|}{ Suffix } & \\
\hline \multirow{4}{*}{ 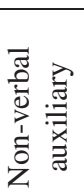 } & \multirow[t]{2}{*}{ Realis } & \multirow[b]{4}{*}{ A } & \multicolumn{2}{|l|}{ Non-past } & \multirow[t]{2}{*}{ Reality } \\
\hline & & & \multicolumn{2}{|l|}{ Past } & \\
\hline & \multirow[t]{2}{*}{ Irrealis } & & \multicolumn{2}{|l|}{ Non-past } & Potentiality \\
\hline & & & \multicolumn{2}{|l|}{ Past } & $\begin{array}{l}\text { Potentiality }+ \\
\text { Non-actualization }\end{array}$ \\
\hline \multirow{4}{*}{ 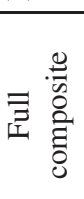 } & \multirow[t]{2}{*}{ Realis } & 1 & Non-Past & Non-Past & \multirow[t]{2}{*}{ Reality } \\
\hline & & & Past & Past & \\
\hline & \multirow[t]{2}{*}{ Irrealis } & & Non-Past & Non-Past (Irrealis) & Potentiality \\
\hline & & & Past- & $\rightarrow$ Past Irrealis & $\begin{array}{l}\text { Potentiality }+ \\
\text { Non-actualization }\end{array}$ \\
\hline \multirow{4}{*}{ 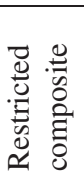 } & \multirow{4}{*}{$\downarrow$} & & \multicolumn{2}{|l|}{ Non-Past } & \multirow[t]{2}{*}{ Reality } \\
\hline & & & \multicolumn{2}{|l|}{ Past } & \\
\hline & & & \multicolumn{2}{|c|}{ Non-Past (Irrealis) } & Potentiality \\
\hline & & & \multicolumn{2}{|c|}{ Past Irrealis } & $\begin{array}{l}\text { Potentiality }+ \\
\text { Non-actualization }\end{array}$ \\
\hline
\end{tabular}


suffixes for realis and irrealis. The top row represents the system which combines the prefixes and suffixes without any verbal stem. The arrows between the rows represent the formal links between the systems and the diachronic hypotheses discussed here: (i) loss of the verbal component for languages with a non-verbal auxiliary (indicated by shading), and (ii) location of mood information in the tense system via separate irrealis tenses, and subsequent loss of mood marking in the prefix system for languages with a restricted composite system (indicated by shading). The last column represents the pragmatically based solution to the semantic problem posed by counterfactual structures, viz. an analysis of non-actualization as originating in an implicature from a combination of past tense and potentiality.

\section{Conclusion: The nature of irrealis and irreality}

From a broader perspective, the problems addressed in the description of composite mood marking in non-Pama-Nyungan languages are exemplary of some of the problems associated with irrealis categories more generally. One of the most puzzling characteristics of irrealis categories across languages, as also noted by Mithun (1995) and Elliott (2000), is that like the broad modal prefix in the composite system studied here, these categories tend to cover uses that encode potential actualization as well as uses that encode or are otherwise associated with non-actualization. The former are found in the classic epistemic, deontic, and desiderative-intentional uses, whereas the latter are found in counterfactual uses, and in associations with negative polarity constructions. As such, however, potential actualization and non-actualization are almost diametrically opposed in semantic and pragmatic terms. The former entails uncertainty about the actualization of an event, and often projects an expectance of actualization (see Traugott \& Dasher 2001) because a speaker judges the event to be desirable or plausible, or because a participant intends to realize it. The latter, on the other hand, entails almost exactly the opposite, i.e., certainty about the non-actualization of an event. This semantic incompatibility raises the question how the frequent association of these two categories with one and the same marker can be explained, and whether it is possible or even necessary to unify these two features into a larger semantic category of irreality. To conclude this study, I will try to show how the discussion of the system of composite mood marking in non-Pama-Nyungan languages can provide a number of ways to deal with the apparent semantic incoherence of irrealis categories across languages.

First of all, the analysis developed here has suggested a possible motivation as to why and how the apparently contradictory features of potentiality and non-actualization come to be grouped together within one category. Specifically, the discussion of counterfactuality has shown how a feature of non- 
actualization can originate as a generalized implicature of the feature of potentiality: when located in a temporal domain that is inherently knowable and therefore within the realm of certainty, use of an expression of potentiality is in salient contrast with a more informative expression of certainty and therefore triggers the implicature that the event described did not take place, i.e., an implicature of non-actualization. In addition to motivating the general association between two apparently incompatible semantic features, the proposed analysis also provides a straightforward explanation for the semantically complex nature of counterfactual constructions, which tend to combine the two features in that they signal non-actualization of an event IN SPITE OF some potentiality.

Secondly, the analysis proposed here could also help to explain another puzzling characteristic of irrealis markers, viz. the frequent association with negative constructions, found both in the non-Pama-Nyungan languages and in a broader crosslinguistic perspective. In the sample investigated here, for instance, eighteen languages out of twenty-eight require a switch from a realis to an irrealis category when some type of negative marker occurs somewhere else in the construction, as is the case with the negative particle $w a$ in Ungarinjin (25).

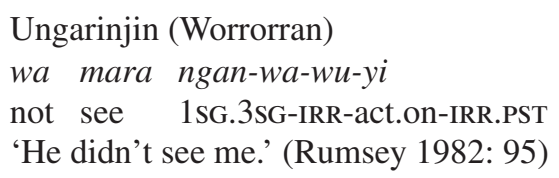

Miestamo (2003: 162-167) investigates the association between irrealis and negation in a worldwide sample of languages, and shows that it is found across various genetic groupings and geographical areas, though usually in less striking proportions than in the non-Pama-Nyungan languages studied here.

The association with negative constructions is surprising at first sight because there is no trace of any feature of potentiality in these constructions, unlike in all other uses recorded so far. In previous studies, the link between potentiality and negation has been explained in various ways, none of which seem to be satisfactory. Mithun (1995) argues that it is a matter of the relative scope of systems of modality and polarity: the use of irrealis in negative constructions reflects that polarity is within the scope of modality in a particular language, while the use of realis suggests that modality is within the scope of polarity. In the absence of independent evidence about such scope relations, however, this is seems to be a formalization of the phenomena rather than an explanation. Givón (1994) suggests that the link with negation is due to the semantic closeness between modality and negation, but this would imply that irrealis is found more often in negative constructions around the world than it actually is (Miestamo 2003: 162-167). The analysis developed in this study suggests 
an alternative explanation, in which counterfactual constructions may form a bridge between the purely modal uses of irrealis markers and their purely polar ones. Specifically, the use of irrealis marking in negative constructions might be regarded as an independent development of the feature of non-actualization found in counterfactual constructions: once an irrealis marker has developed an additional feature of non-actualization in counterfactual constructions, the category of irrealis could also be associated with non-actualization in general, irrespective of the presence or absence of additional features of potentiality. This hypothesis could easily be tested empirically: given that counterfactuality is regarded as the bridge to negative uses, the analysis predicts that irrealis will only be used in negative constructions in those languages where it is also used in counterfactual constructions, and where implicature of non-actualization has become semanticized.

A final problem that might be clarified by the analysis developed in this study is the question of the viability of irrealis as a semantic category in the description of mood. Bybee (1998) has argued explicitly against the usefulness of such a category, claiming that it is impossible to come up with a clear semantic core for categories described as irrealis across languages, and that such categories can usually be described in terms of more basic categories that do show commonalities across languages like epistemic, deontic, or agentoriented modality. While it is true that most of the uses of irrealis discussed for the non-Pama-Nyungan languages involve such supposedly basic components, epistemic or deontic modality, as shown in Section 2.2, a description of the irrealis markers in the sample that remains restricted to these supposedly more basic terms would miss a number of significant generalizations. Most importantly, it would miss the link between these categories and the feature of non-actualization in past contexts that defines counterfactual constructions as a subset of irrealis in all languages in the sample. In addition, it would also miss the link with negative constructions, which is not found universally but nonetheless occurs in the majority of languages in the sample. More generally, what this means is that at least for the non-Pama-Nyungan languages it is in fact possible to establish a robust core meaning for the category of irrealis, represented as Table 7.

From a broader, crosslinguistic perspective, at least two of the three cells in Table 7 are solidly linked. The functional basis of the link between past potentiality and non-actualization in counterfactual constructions suggests that it will be widely attested across languages, and a preliminary study has established that in the large majority of languages in a broad sample of 52 areally and genetically diverse languages (as in all of the languages investigated here), counterfactual constructions formally combine a component of potentiality with a component of past tense (Verstraete \& Van Linden 2004). What this means is that in all of these languages there is a category that is semantically comparable 
Table 7. The semantic structure of irrealis

\begin{tabular}{|c|c|c|c|}
\hline \multicolumn{4}{|c|}{ Irrealis } \\
\hline \multicolumn{3}{|c|}{ Potential actualization - } & \multirow{2}{*}{+ Past } \\
\hline Epistemic & Deontic & Desiderative-intentional & \\
\hline & & & Non-actualization \\
\hline
\end{tabular}

to the irrealis categories studied here in that it covers both potentiality and past potentiality combined with non-actualization, i.e., counterfactuality. In some of these languages, moreover, the category will be further extended to negative contexts, with the feature of non-actualization but without potentiality. Of course, not all descriptions of these languages will use the label irrealis for this category, but given the robust nature of its basic semantic features and the links between them, I believe that the category represented in Table 7 is a good example of a crosslinguistically applicable definition of irrealis that goes beyond the classic types of epistemic, deontic, and desiderative-intentional modality advocated as primitives in Bybee (1998).

Received: 23 February 2004

Revised: 2 March 2005

Katholieke Universiteit Leuven University of Melbourne

Correspondence address: Departement Linguïstiek, Katholieke Universiteit Leuven, BlijdeInkomststraat 21, 3000 Leuven, Belgium; e-mail: jean-christophe.verstraete@arts.kuleuven.ac.be

Acknowledgements: This paper was written while I was a visiting research fellow at the Department of Linguistics of the University of Melbourne. I would like to thank the department for its hospitality and the excellent working conditions it offered, as well as the Fund for Scientific Research - Flanders for its financial support. Parts of this study were presented in seminars at the University of Melbourne and the University of Western Australia, and at the 5th International Conference of the Association for Linguistic Typology in Cagliari. I am grateful to the editor-inchief and four Linguistic Typology reviewers for very detailed and helpful comments on an earlier version of this paper, and to Bruce Birch, Alan Dench, Nick Evans, Ian Green, Shelly Harrison, Ekkehard König, Alexander Loengarov, Bill McGregor, Rachel Nordlinger, Marie-Eve Ritz, Adam Saulwick, and Ruth Singer for very useful comments or for sharing relevant data. I am of course solely responsible for errors of fact or interpretation.

Abbreviations: A agent, ABS absolutive, ACC accusative, ANAPH anaphoric element, AUG augmented, CF counterfactual, CLF classifier, CTV continuative, DAT dative, DEF definite, DEFAUGM defined augmented, DIST distal, DL dual, ERG ergative, EXP expectation, FUT future, HABIT habitual, IMPF imperfective, IRR irrealis, LOC locative, M masculine, MID middle, MIN minimal, MPROP modal proprietive, NACT nonactual, NC noncomplete, NEG negation, NF nonfuture, NMIN non-minimal, NOM nominative, NPST nonpast, NSG nonsingular, o object, OBL oblique, ORIG origin, PFV perfective, PL plural, PNCT punctiliar, POT potential, PRIV privative, PRS present, PST past, PURP purposive, $\mathrm{R}$ realis, REDUP reduplication, REL relative, RESTR restricted, RR reflexive-reciprocal, $\mathrm{S}$ subject, SG singular, SUBJ subjunctive, TH thematic, TWD towards; I, II, III gender; 1, 2, 3 person; BINI, MA, 
NJ, RA, and WU2 are unglossed elements; = marks a boundary before a verb root (Nunggubuyu), + marks a morpheme boundary within the (verbal) classifier complex (Gooniyandi), / and \ mark rising and falling intonation (Jaminjung).

Appendix 1: Non-Pama-Nyungan languages investigated, with their genetic affiliation (based on Evans 2003b)

\begin{tabular}{|c|c|c|}
\hline Language & Genetic affiliation & Source(s) \\
\hline Bininj Gun-Wok & Gunwinyguan & Evans 2003a \\
\hline Bunuba & Bunuban & Rumsey 2000 \\
\hline Emmi & Western Daly & Ford 1998 \\
\hline Gaagudju & Gaagudju & Harvey 1992, 2002 \\
\hline Gooniyandi & Bunuban & McGregor 1990, p.c. \\
\hline Iwaidja & Iwaidjan & Pym \& Larrimore 1979, Birch p.c. \\
\hline Jaminjung & Mindi & Schultze-Berndt 2000 \\
\hline Kayardild & Tangkic & Evans 1995 \\
\hline Limilngan & Limilngan & Harvey 2001 \\
\hline Mangarayi & Gunwinyguan (or Maran) ${ }^{\mathrm{a}}$ & Merlan 1982 \\
\hline Mara & Maran & Heath 1981 \\
\hline Marrithiyel & Western Daly & Green 1989, p.c. \\
\hline Maung & Iwaidjan & $\begin{array}{l}\text { Capell \& Hinch } 1970 \text {, } \\
\text { Singer 2003, p.c. }\end{array}$ \\
\hline Nakkara & Maningrida & Eather 1990 \\
\hline Ndjébbana & Maningrida & McKay 2000 \\
\hline Ngalakan & Gunwinyguan & Merlan 1983 \\
\hline Ngandi & Gunwinyguan & Heath 1978 \\
\hline Nunggubuyu & Gunwinyguan & Heath 1980b, 1984 \\
\hline Nyikina & Nyulnyulan & Stokes 1982 \\
\hline Rembarrnga & Gunwinyguan & McKay 1975 , Saulwick 2003, p.c. \\
\hline Ungarinjin & Worrorran & Rumsey 1982 \\
\hline Wagiman & Yangmanic & Cook 1987, Wilson 1999 \\
\hline Wambaya & Mindi & Nordlinger 1998, p.c. \\
\hline Warray & Gunwinyguan & Harvey 1986 \\
\hline Wardaman & Yangmanic & Merlan 1994 \\
\hline Warndarang & Maran & Heath 1980a \\
\hline Worrorra & Worrorran & Clendon 2000 \\
\hline Yukulta & Tangkic & Keen 1983 \\
\hline
\end{tabular}

Note

a The genetic status of Mangarayi as a Gunwinyguan language is contested, see Merlan (2003), who argues that it could also belong to the Maran languages. 


\section{Appendix 2: Patterns of composite mood marking in the sample}

The labels in the first two columns are taken from the primary sources, while the abbreviations in the third column are standardized, using my own terminology for types of modal meaning (see Section 2.2):

- APPR apprehensive, CF counterfactual, DES desiderative, DEO deontic, EP epistemic, EVID evidential, FUT future, HAB habitual, IMM imminent, INT intentional, NEG negative.

- Features between brackets indicate domains of application for the type of modality in question, concerning person, tense, or other modal categories.

- Shading indicates the relevant part of the system (see Section 2.1). 


\section{Jean-Christophe Verstraete}

\section{Languages with prefix-suffix systems for mood marking}

\subsection{Full prefix-suffix systems}

Bunuba (Rumsey 2000)

\begin{tabular}{|c|c|c|c|}
\hline Prefix & Suffix & Modal meaning & \\
\hline INDICATIVE & PAST & & \\
\hline 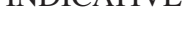 & $\varnothing$ & & \\
\hline FUTURE & $\varnothing$ & $\begin{array}{l}\text { FUT } \\
\operatorname{DEO}(1,2,3)\end{array}$ & $(90-92)$ \\
\hline \multirow{3}{*}{ IRREALIS } & PAST & $\begin{array}{l}\text { CF(DEO, INT, EP) } \\
\text { NEG(PST) }\end{array}$ & (92) \\
\hline & PRESENT IRREALIS & $\begin{array}{l}\text { INT } \\
\text { DEO } \\
\text { NEG(PRS) }\end{array}$ & (92) \\
\hline & $\varnothing$ & $\begin{array}{l}\text { EP } \\
\text { NEG(FUT) } \\
\text { NEG(DEO(2)) }\end{array}$ & $(92-93)$ \\
\hline
\end{tabular}

Emmi (Ford 1998)

\begin{tabular}{|l|l|ll|}
\hline Prefix & Suffix & Modal meaning & \\
\hline \multirow{2}{*}{ REALIS } & $\varnothing$ & & \\
& PERFECT & & $(161)$ \\
\hline \multirow{2}{*}{ IRREALIS } & $\varnothing$ & DEO(2) & $(161)$ \\
& & INT & $(157$, \\
\cline { 2 - 4 } & PERFECT & CF(EP) & $159)$ \\
\hline
\end{tabular}

Gaagudju (Harvey 2002)

\begin{tabular}{|c|c|c|c|}
\hline \multirow{2}{*}{\begin{tabular}{|l|} 
Prefix \\
UNMARKED
\end{tabular}} & \multirow{3}{*}{$\begin{array}{l}\text { Suffix } \\
\text { PAST PERFECTIVE } \\
\text { PAST IMPERFECTIVE }\end{array}$} & \multicolumn{2}{|l|}{ Modal meaning } \\
\hline & & & \\
\hline & & & \\
\hline & EVITATIVE & $\begin{array}{l}\text { APPR } \\
\text { EP } \\
\text { NEG(FUT) }\end{array}$ & $\begin{array}{l}(236-237 \\
250-251)\end{array}$ \\
\hline PRESENT & PRESENT & NEG(DEO(2)) & $\begin{array}{l}(236-237, \\
248-249)\end{array}$ \\
\hline \multirow[t]{2}{*}{ IRREALIS } & PAST IMPERFECTIVE & $\begin{array}{l}\text { CF(EP, DEO) } \\
\text { NEARLY } \\
\text { DES(PST) } \\
\text { NEG(PST) }\end{array}$ & $\begin{array}{l}(236-237 \\
246-248)\end{array}$ \\
\hline & FUTURE & $\begin{array}{l}\text { DEO } \\
\text { DES/INT }\end{array}$ & $\begin{array}{l}(236-237 \\
250-251)\end{array}$ \\
\hline$\varnothing$ & IMPERATIVE & $\operatorname{DEO}(2)$ & $\begin{array}{l}(236-237 \\
254-258)\end{array}$ \\
\hline
\end{tabular}


Gooniyandi (McGregor 1990)

\begin{tabular}{|c|c|c|c|c|}
\hline Prefix 1 & Prefix 2 & Suffix & Modal meaning & \\
\hline \multirow{3}{*}{ INDICATIVE } & PAST & & \multirow[b]{3}{*}{\begin{tabular}{|l} 
FUT \\
$\mathrm{DEO}(2)$
\end{tabular}} & \multirow[b]{3}{*}{$(520-523)$} \\
\hline & PRESENT & & & \\
\hline & FUTURE & & & \\
\hline \multirow[t]{3}{*}{ SUBJUNCTIVE } & PAST & & EVID & $(550-551)$ \\
\hline & IRREALIS & & $\mathrm{CF}(\mathrm{DEO}, \mathrm{EP}, \mathrm{DES})$ & $(548-550)$ \\
\hline & FUTURE & & $\begin{array}{l}\text { DEO } \\
\text { EP } \\
\text { DES }\end{array}$ & $(545-548)$ \\
\hline & FUTURE & DESIDERATIVE & $\operatorname{DEO}(1,2,3)$ & $(530-532)$ \\
\hline & IRREALIS & \multirow[t]{2}{*}{ POTENTIAL } & $\begin{array}{l}\text { CF(EP, DEO, DES) } \\
\text { NEARLY }\end{array}$ & $(532-537)$ \\
\hline & FUTURE & & EP & $(537-539)$ \\
\hline & PRESENT & DEFINITE & $\begin{array}{l}\text { APPR } \\
\text { NEG(DEO(2)) }\end{array}$ & $(541-542)$ \\
\hline
\end{tabular}

Iwaidja (Pym \& Larrimore 1979, Birch p.c.)

\begin{tabular}{|c|c|c|c|}
\hline Prefix & Suffix & Modal meaning & \\
\hline \multirow{3}{*}{$\varnothing$} & PAST & & \\
\hline & $\varnothing$ [PRESENT] & NEG(DEO(2)) & (104) \\
\hline & OPTATIVE & DES & (74) \\
\hline \multirow{2}{*}{ IMPERATIVE } & OPTATIVE & DEO(intr, tr3) & (74) \\
\hline & FRUSTRATIVE & $\mathrm{CF}(\mathrm{DEO}, \mathrm{INT})$ & (76) \\
\hline \multirow[t]{2}{*}{ FUTURE } & $\varnothing$ & 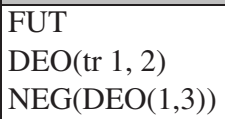 & (94-99) \\
\hline & \begin{tabular}{|l|} 
PAST \\
\end{tabular} & & \\
\hline
\end{tabular}

Jaminjung (Schultze-Berndt 2000)

\begin{tabular}{|l|l|l|ll|}
\hline Prefix 1 & Prefix 2 & Suffix & Modal meaning & \\
\hline \multirow{3}{*}{ IRREALIS } & & $\varnothing$ & $\begin{array}{l}\text { APPR } \\
\text { NEG(DEO(2)) } \\
\text { NEG(EP) }\end{array}$ & $(93-94)$ \\
\hline INDICATIVE & $\begin{array}{l}\text { FUTURE/ } \\
\text { POTEN- } \\
\end{array}$ & TIAL & $\begin{array}{l}\text { EP } \\
\text { DEO } \\
\text { DEST }\end{array}$ & CF(INT) \\
\cline { 3 - 5 } & & IMPERFECTIVE & DES(PST) & $(92)$ \\
\hline IMPERATIVE & & $\varnothing$ & DEO(2) & $(94)$ \\
\hline
\end{tabular}


Limilngan (Harvey 2001)

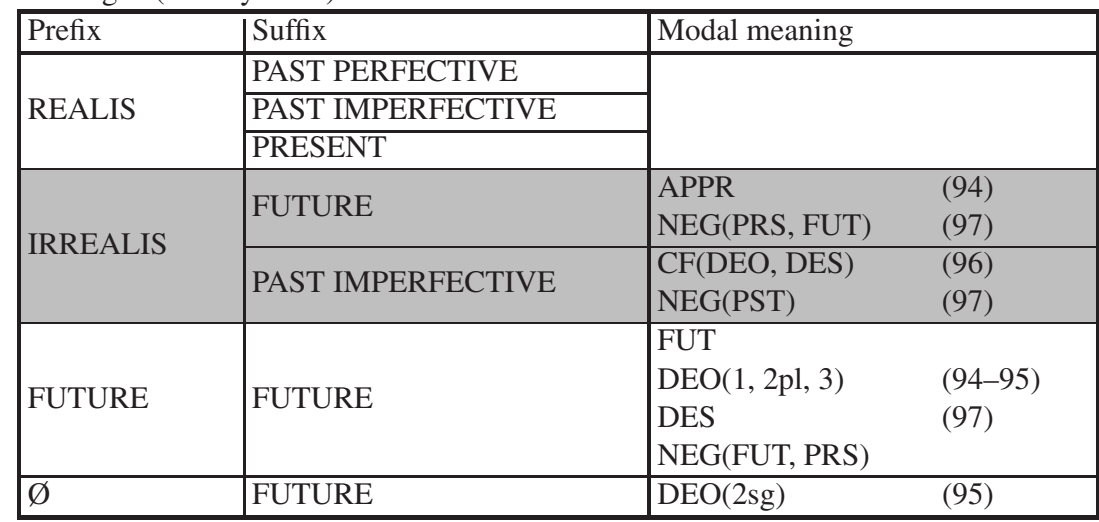

Mangarayi (Merlan 1982)

\begin{tabular}{|c|c|c|c|}
\hline Prefix & Suffix & \multicolumn{2}{|l|}{ Modal meaning } \\
\hline REALIS & NON-PAST & & \\
\hline$\varnothing$ & PAST & & \\
\hline \multirow{3}{*}{ IRREALIS } & NON-PAST & $\begin{array}{l}\mathrm{EP} \\
\mathrm{DEO}(1,2)\end{array}$ & $(145-146)$ \\
\hline & PAST & EVID & $(150)$ \\
\hline & $\begin{array}{l}\text { DESIDERATIVE- } \\
\text { INTENTIONAL }\end{array}$ & DES/INT & $(147-148)$ \\
\hline \multirow{3}{*}{$\varnothing$} & NON-PAST & $\begin{array}{l}\text { NEG(PRS) } \\
\text { NEG(DEO) } \\
\text { APPR }\end{array}$ & $(146-147)$ \\
\hline & PAST NEGATIVE & $\begin{array}{l}\mathrm{CF}(\mathrm{DEO}, \mathrm{INT}) \\
\mathrm{DES}(\mathrm{PST})[+\mathrm{DI}] \\
\mathrm{NEG}(\mathrm{PST})\end{array}$ & $(150-151)$ \\
\hline & IMPERATIVE & $\begin{array}{l}\mathrm{DEO}(2) \\
\mathrm{NEG}(\mathrm{DEO}(2))\end{array}$ & $(141-142)$ \\
\hline
\end{tabular}

Marrithiyel (Green 1989)

\begin{tabular}{|l|l|ll|}
\hline Prefix & Suffix & Modal meaning & \\
\hline \multirow{3}{*}{ REALIS } & PAST & & \\
\cline { 2 - 4 } & PRESENT & & $(164-170)$ \\
\cline { 2 - 4 } & APPREHENSIVE & APPR & $(154-156)$ \\
\hline \multirow{4}{*}{ IRREALIS } & PAST & CF(DEO, EP, DES) & $(156-158)$ \\
\cline { 2 - 4 } & PAST IRREALIS & CF(DEO) & \\
\cline { 2 - 4 } & PRESENT & DEO(1,2,3) & $(160-164)$ \\
\cline { 2 - 4 } & & FUT & \\
& FUTURE & DEO & $(151-154)$ \\
& & DES & \\
\hline
\end{tabular}


Nakkara (Eather 1990)

\begin{tabular}{|l|l|l|}
\hline Prefix & Suffix & Modal meaning \\
\hline \multirow{3}{*}{ IRREALIS 1 } & FUTURE & FUT \\
\cline { 2 - 3 } & ma & $\begin{array}{l}\text { CF(EP) } \\
\text { NEG(PST) }\end{array}$ \\
\hline \multirow{3}{*}{ REALIS } & CONTEMPORARY & \\
\cline { 2 - 3 } & PRE-CONTEMPORARY & \\
\cline { 2 - 4 } & $\varnothing$ & NEG(PRS, FUT) [+-ka](197-191) \\
\hline
\end{tabular}

Ndjébbana (McKay 2000)

\begin{tabular}{|c|c|c|c|c|c|}
\hline Prefix 1 & Prefix 2 & Prefix 3 & |Suffix & Modal meaning & \multirow{3}{*}{$\frac{(223)}{(223-224)}$} \\
\hline \multirow{6}{*}{$\begin{array}{l}\text { [INDICA- } \\
\text { TIVE] }\end{array}$} & \multirow[b]{2}{*}{ IRREALIS } & \multirow[b]{5}{*}{$\begin{array}{l}\text { AVERSA- } \\
\text { TIVE } \\
\end{array}$} & \multirow{2}{*}{\begin{tabular}{|l} 
FUTURE \\
COUNTER \\
FACTUAL \\
\end{tabular}} & \multirow{2}{*}{$\begin{array}{l}\text { FUT } \\
\text { CF(EP, DEO, INT) } \\
\text { NEG(PST) }\end{array}$} & \\
\hline & & & & & \\
\hline & \multirow{5}{*}{ REALIS } & & \multirow{3}{*}{\begin{tabular}{|l} 
REMOTE \\
CON- \\
TEM- \\
PORARY \\
\end{tabular}} & & \\
\hline & & & & & \\
\hline & & & & APPR & $(225-226)$ \\
\hline & & & FUTURE & NEG(PRS, FUT) & $(224-225)$ \\
\hline $\begin{array}{l}\text { IMPERA } \\
\text { TIVE }\end{array}$ & & & & DEO(2) & $(225)$ \\
\hline
\end{tabular}

Nunggubuyu (Heath 1984)

\begin{tabular}{|c|c|c|c|}
\hline Prefix & Suffix & Modal meani & \\
\hline \multirow{3}{*}{$\begin{array}{l}\text { IRREALIS } \\
\text { (= 'B' prefix } \\
\text { series) }\end{array}$} & NONPAST2 & $\begin{array}{l}\text { FUT } \\
\text { DEO(2,3) }\end{array}$ & $\begin{array}{l}(338-339, \\
343-344)\end{array}$ \\
\hline & NONPAST1 & $\begin{array}{l}\text { FUT } \\
\text { DEO }(2,3) \\
\text { NEG(PRS) }\end{array}$ & $\begin{array}{l}(338-339, \\
343-344)\end{array}$ \\
\hline & PAST2 & $\begin{array}{l}\text { CF(EP, DEC } \\
\text { IMM) }\end{array}$ & $(345-346)$ \\
\hline \multirow{5}{*}{$\begin{array}{l}\text { REALIS } \\
\text { (= 'A' prefix } \\
\text { series) }\end{array}$} & PAST1 & & \\
\hline & PAST2 & & \\
\hline & \begin{tabular}{|l|} 
NONPAST2 \\
\end{tabular} & & \\
\hline & NONPAST3 & $\begin{array}{l}\text { NEG(FUT) } \\
\text { APPR }\end{array}$ & $\begin{array}{l}(339) \\
(346)\end{array}$ \\
\hline & EVITATIVE & APPR & (346) \\
\hline
\end{tabular}


Nyikina (Stokes 1982)

\begin{tabular}{|c|c|c|c|c|}
\hline Prefix 1 & Prefix 2 & Suffix & Modal meaning & \\
\hline & & PRESENT & & \\
\hline & & PAST (2) & & \\
\hline \multirow{4}{*}{ FUTURE } & REALIS & \multirow{3}{*}{$\varnothing$} & $\begin{array}{l}\text { FUT } \\
\text { DEO(2) }\end{array}$ & $(275-276)$ \\
\hline & & & INT & \\
\hline & \multirow[b]{2}{*}{ IRREALIS } & & $\begin{array}{l}\text { EP } \\
\text { NEG(PRS) }\end{array}$ & $\begin{array}{l}(282) \\
(289-281)\end{array}$ \\
\hline & & PAST & $\begin{array}{l}\text { CF(DEO, EP, INT) } \\
\text { NEG(PST) }\end{array}$ & $\begin{array}{l}(281, \\
327-330) \\
(281)\end{array}$ \\
\hline
\end{tabular}

Ungarinjin (Rumsey 2000)

\begin{tabular}{|c|c|c|c|c|c|}
\hline \multirow{2}{*}{ Prefix 1} & \multirow{2}{*}{ Prefix 2} & \multirow{3}{*}{$\begin{array}{l}\text { Prefix } 3 \\
\text { INDICA- } \\
\text { TIVE }\end{array}$} & Suffix & \multicolumn{2}{|l|}{ Modal meaning } \\
\hline & & & PAST & & \\
\hline & \multirow[t]{4}{*}{ FUTURE } & & PRESENT & $\begin{array}{l}\text { FUT } \\
\text { INT }\end{array}$ & $(87-89)$ \\
\hline & & & $\begin{array}{l}\text { PAST } \\
\text { IRREALIS }\end{array}$ & $\begin{array}{l}\text { CF(DEO) [+ prt] } \\
\text { NEG(PST) }\end{array}$ & $\begin{array}{l}(171) \\
(89-95)\end{array}$ \\
\hline & & IRR & NONPAST & $\begin{array}{l}\text { EP [+ prt] } \\
\text { NEG(DEO, FUT) }\end{array}$ & $\begin{array}{l}(169-170) \\
(100-102)\end{array}$ \\
\hline & & OPT & \begin{tabular}{|l} 
PAST \\
IRREALIS
\end{tabular} & $\operatorname{DEO}(1,2,3)$ & $(95-96)$ \\
\hline \multicolumn{2}{|c|}{ IMPERATIVE } & & & $\mathrm{DEO}(2)$ & $(96-100)$ \\
\hline
\end{tabular}

Wagiman (Wilson 1999)

\begin{tabular}{|c|c|c|}
\hline Prefix & Suffix & Modal meaning \\
\hline \multirow{3}{*}{ PAST } & PAST & \\
\hline & PAST PERFECTIVE & \\
\hline & PAST HABITUAL & \\
\hline PRESENT & PRESENT & \\
\hline \multirow[b]{2}{*}{ FUTURE } & FUTURE & \multirow{2}{*}{$\begin{array}{l}\text { FUT } \\
\operatorname{DEO}(2) \\
\operatorname{NEG}(\operatorname{DEO}(2))\end{array}$} \\
\hline & FUTURE/IRREALIS & \\
\hline \multirow{3}{*}{ IRREALIS } & PAST (PERFECTIVE) & \\
\hline & FUTURE & $\begin{array}{l}\text { APPR } \\
\text { NEG(FUT) }\end{array}$ \\
\hline & PRESENT & NEG(PRS) \\
\hline
\end{tabular}


Warray (Harvey 1986)

\begin{tabular}{|c|c|c|c|}
\hline Prefix & Suffix & Modal meaning & \\
\hline \multirow{3}{*}{ POTENTIAL } & IRREALIS & $\begin{array}{l}\text { CF(DEO, INT, } \\
\text { NEARLY, DES }) \\
\text { EP(PST) } \\
\text { NEG(PST) }\end{array}$ & $\begin{array}{l}(144-145) \\
(146) \\
(143-144)\end{array}$ \\
\hline & NON-COMPLETE & $\begin{array}{l}\text { EP } \\
\text { NFG(PRS) }\end{array}$ & $\begin{array}{l}(146) \\
(143-144)\end{array}$ \\
\hline & \begin{tabular}{|l} 
IMPERATIVE \\
\end{tabular} & NEG(DEO) & $(150)$ \\
\hline \multirow{2}{*}{ COMPLETE } & IRREALIS & $\mathrm{DEO}(1)$ & $(151)$ \\
\hline & IMPERATIVE & $\mathrm{DEO}(2)$ & $(150)$ \\
\hline \multirow{3}{*}{$\begin{array}{l}\text { NON- } \\
\text { COMPLETE }\end{array}$} & REALIS & $\begin{array}{l}\text { FUT(1) } \\
\text { INT(1) } \\
\text { NEARLY(1) }\end{array}$ & $\begin{array}{l}(145-146, \\
152)\end{array}$ \\
\hline & IRREALIS & FUT(2,3) & $(152)$ \\
\hline & IRREALIS + DATIVE & DES & $(154)$ \\
\hline
\end{tabular}

Wardaman (Merlan 1984)

\begin{tabular}{|l|l|ll|}
\hline Prefix & Suffix & Modal meaning & \\
\hline \multirow{5}{*}{ INDICATIVE } & PAST & & $(183-184)$ \\
\cline { 2 - 4 } & PRESENT & DEO $(1,3)$ & $(179-181)$ \\
\cline { 2 - 4 } & FUTURE & $\begin{array}{l}\text { DEO } \\
\text { INT }\end{array}$ & $(178-179)$ \\
\cline { 2 - 4 } & POTENTIAL & EP & $(181-183)$ \\
\cline { 2 - 4 } & $\varnothing$ & DEO(2) & $(184-185)$ \\
\hline \multirow{3}{*}{ IRREALIS } & $\varnothing$ & APPR & $(188)$ \\
\cline { 2 - 4 } & PAST & CF(EP, DEO) & \\
\cline { 2 - 4 } & PRESENT & NEG(DEO) & $(186-188)$ \\
\hline
\end{tabular}

Warndarang (Heath 1980a)

\begin{tabular}{|c|c|c|c|}
\hline Prefix & Suffix & Modal meaning & \\
\hline \multirow{3}{*}{ POTENTIAL } & PAST IRREALIS & CF(EP, IMM, DEO) & $(61)$ \\
\hline & PRESENT IRREALIS & DEO & $(61)$ \\
\hline & FUTURE & $\begin{array}{l}\text { FUT } \\
\text { EP }\end{array}$ & $(61)$ \\
\hline \multirow{3}{*}{ NEGATIVE } & PAST IRREALIS & NEG(PST) & $(59-60)$ \\
\hline & \begin{tabular}{|l} 
PRESENT IRREALIS \\
\end{tabular} & NEG(PRS) & $(59-60)$ \\
\hline & FUTURE NEGATIVE & $\begin{array}{l}\text { NEG(FUT) } \\
\text { NEG(DEO(2)) }\end{array}$ & $(59-60)$ \\
\hline \multirow{2}{*}{$\varnothing$} & IMPERATIVE & $\mathrm{DEO}(2 \mathrm{SG})$ & $(84)$ \\
\hline & FUTURE NEGATIVE & DEO(other) & (84) \\
\hline
\end{tabular}


Worrorra (Clendon 2000)

\begin{tabular}{|c|c|c|c|c|}
\hline Prefix 1 & Prefix 2 & Suffix & Modal meaning & \\
\hline & & PRESENT & & \\
\hline & & PAST & & \\
\hline & FUTURE & $\varnothing$ & FUT & $\begin{array}{l}(60-61, \\
84-86)\end{array}$ \\
\hline & $\begin{array}{l}\text { SUB- } \\
\text { JUNCTIVE }\end{array}$ & \begin{tabular}{|l}
$\varnothing$ \\
PAST \\
IRREALIS
\end{tabular} & $\begin{array}{l}\text { EP } \\
\text { CF(DEO, NEARLY) }\end{array}$ & $\begin{array}{l}(72-73) \\
(74, \\
86-87)\end{array}$ \\
\hline \multirow{4}{*}{ IRREALIS } & & $\begin{array}{l}\text { PAST } \\
\text { IRREALIS }\end{array}$ & $\begin{array}{l}\mathrm{CF}(\mathrm{DEO}) \\
\mathrm{NEG(PST)}\end{array}$ & $\begin{array}{l}(66-67, \\
88)\end{array}$ \\
\hline & & PRESENT & DEO & (67) \\
\hline & & IRREALIS & NEG(PRS, FUT) & $(64-65)$ \\
\hline & & $\varnothing$ & APPR & $(67-68)$ \\
\hline
\end{tabular}

1.2. Restricted prefix-suffix systems

Bininj Gun-Wok (Evans 2003)

\begin{tabular}{|l|l|lr|}
\hline Prefix & Suffix & \multicolumn{3}{|l|}{ Modal meaning } \\
\hline \multirow{5}{*}{ NONPAST } & \multirow{4}{*}{ NONPAST } & FUT & $(364-365)$ \\
& & NEG(PRS, FUT, DEO)(365-366) \\
& & DEO & $(366-367)$ \\
& IMPERATIVE & APPR & $(366-367)$ \\
\hline \multirow{5}{*}{ PAST } & DEO(1,2) & $(362-363)$ \\
\cline { 2 - 4 } & PAST PERFECTIVE & & $(363)$ \\
\cline { 2 - 4 } & PAST IMPERFECTIVE & & \\
\cline { 2 - 4 } & & NEG(PST) & \\
& & CF(NEARLY, DES, & $(373)$ \\
& IRREALIS & INT) & $(373-374)$ \\
& & CF(DEO - PRS \& & $(374-375)$ \\
& & PST) & \\
\hline
\end{tabular}


Maung (Singer 2003)

\begin{tabular}{|l|l|l|}
\hline Prefix & Suffix & Modal meaning \\
\hline \multirow{4}{*}{} & \multirow{2}{*}{ IRREALIS 1 } & EP \\
& & APPR \\
& NEG(PRS, FUT) \\
\cline { 2 - 3 } & IRREALIS 2 & CF(DEO, EP) \\
& NEG(PST) \\
& DEO(1,2) \\
\cline { 2 - 3 } & PAST CONTINUOUS & \\
\cline { 2 - 3 } & PAST PUNCTUAL & \\
\cline { 2 - 3 } & & NEG(DEO(2)) \\
\hline \multirow{2}{*}{ FUTURE } & PRESENT & FUT \\
& & DEO(2) \\
\hline
\end{tabular}

Ngalakan (Merlan 1983)

\begin{tabular}{|c|c|c|c|}
\hline Prefix & Suffix & \multicolumn{2}{|l|}{ Modal meaning } \\
\hline & PAST & & \multirow[t]{2}{*}{$(108)$} \\
\hline & PRESENT & & \\
\hline & FUTURE & \begin{tabular}{|l} 
FUT \\
DEO(2) \\
DES/INT [sts + \\
$\quad$ DI suffix]
\end{tabular} & $\begin{array}{l}(100) \\
(101) \\
(105-106)\end{array}$ \\
\hline & \multirow[t]{2}{*}{ POTENTIAL } & \begin{tabular}{|l} 
EP \\
DEO \\
CF(DEO, DES) \\
[sts + PURP] \\
NEG(PST, PRS)
\end{tabular} & $(102-103)$ \\
\hline \multirow[t]{2}{*}{ warna } & & $\mathrm{CF}(\mathrm{DEO}, \mathrm{DES})$ & (97) \\
\hline & \multirow{3}{*}{ EVITATIVE } & NEG(FUT, DEO) & $(101)$ \\
\hline -mele(?)- & & APPR & $(96-97,102)$ \\
\hline -wañ?- & & NEG(DEO) & $(97,104)$ \\
\hline
\end{tabular}

Ngandi (Heath 1978)

\begin{tabular}{|c|c|c|c|}
\hline \multirow{3}{*}{ Prefix } & Suffix & \multicolumn{2}{|l|}{ Modal meaning } \\
\hline & FUTURE & $\begin{array}{l}\text { FUT } \\
\text { EP } \\
\mathrm{DEO}(2)\end{array}$ & (105-106) \\
\hline & POTENTIAL & $\begin{array}{l}\text { CF(EP, DEO, IMM) } \\
\text { DEO }\end{array}$ & (106) \\
\hline \multirow[t]{4}{*}{ mili } & EVITATIVE & APPR & $(81,106)$ \\
\hline & PAST NEGATIVE & NEG(PST) & $(103-103)$ \\
\hline & PRESENT NEGATIVE & NEG(PRS) & $(102-103)$ \\
\hline & FUTURE NEGATIVE & NEG(FUT) & $(102-103)$ \\
\hline
\end{tabular}


Rembarrnga (McKay 1975)

\begin{tabular}{|c|c|c|c|}
\hline Prefix & Suffix & Modal meaning & \\
\hline & PAST & & \\
\hline & & FUT & $(129-130)$ \\
\hline & & DEO & $(234-235)$ \\
\hline & FUTURE & INT & $(233-234)$ \\
\hline & & $\operatorname{NEG}(\mathrm{DEO}(2))$ & $(240)$ \\
\hline & & NEG(FUT) & $(237-238)$ \\
\hline & \multirow{3}{*}{ PAST COUNTERFACTUAL } & CF(INT, DEO) & $(233-235)$ \\
\hline & & NEG(PST) & $(237-238)$ \\
\hline \multirow{2}{*}{ LEST } & & APPR & $(181-183)$ \\
\hline & PRESENT & APPR & $(181-183)$ \\
\hline
\end{tabular}

2. Languages with non-verbal auxiliaries for mood marking

Wambaya (Nordlinger 1998)

\begin{tabular}{|c|c|c|c|}
\hline AUX & Verb suffix & Modal meaning & \\
\hline PAST & NON-FUTURE & & \\
\hline \multirow{2}{*}{ PRESENT } & \multirow{2}{*}{$\begin{array}{l}\text { NON-FUTURE } \\
\text { FUTURE }\end{array}$} & NEG(DEO(2)) & $(162)$ \\
\hline & & $\mathrm{DEO}(2)$ & $(161-162)$ \\
\hline \multirow[t]{2}{*}{ FUTURE } & NON-FUTURE & $\begin{array}{l}\text { FUT } \\
\text { NEG(FUT) }\end{array}$ & $(144-145)$ \\
\hline & FUTURE & $\begin{array}{l}\text { FUT } \\
\mathrm{DEO}(2)\end{array}$ & $(161-162)$ \\
\hline NON-ACTUAL PAST & \multirow{3}{*}{ NON-FUTURE } & $\begin{array}{l}\text { CF(DEO, EP) } \\
\text { NEG(PST) }\end{array}$ & $(149-150)$ \\
\hline NON-ACTUAL PRESENT & & NEG(PRS) & $(149-150)$ \\
\hline HYPOTHETICAL & & $\begin{array}{l}\text { EP } \\
\text { APPR } \\
\text { NEG(FUT) }\end{array}$ & $(150-151)$ \\
\hline
\end{tabular}


Yukulta (Keen 1983)

\begin{tabular}{|l|l|ll|}
\hline Clitic complex & Verb suffix & Modal meaning & \\
\hline PAST REALIS & INDICATIVE & & $(221)$ \\
\hline PAST IRREALIS & INDICATIVE & CF(NEARLY) & \\
\hline \multirow{2}{*}{$\begin{array}{l}\text { PRESENT } \\
\text { REALIS }\end{array}$} & INDICATIVE & & $(238-239)$ \\
\cline { 2 - 4 } & $\begin{array}{l}\text { DESIDERATIVE } \\
\text { REALIS }\end{array}$ & DES \\
\hline \multirow{2}{*}{ PRESENT IRREALIS } & $\begin{array}{l}\text { NEGATIVE } \\
\text { INDICATIVE }\end{array}$ & $\begin{array}{l}\text { NEG(PRS) } \\
\text { IRREALIS }\end{array}$ & DES \\
\cline { 2 - 4 } & $\begin{array}{l}\text { NEGATIVE } \\
\text { DESIDERATIVE }\end{array}$ & DES \\
\hline \multirow{2}{*}{ FUTURE REALIS } & $\begin{array}{l}\text { NEGATIVE } \\
\text { DESIDERATIVE }\end{array}$ & DES & $(239)$ \\
\hline \multirow{2}{*}{$\begin{array}{l}\text { FUTURE } \\
\text { IRREALIS }\end{array}$} & INDICATIVE & EP & $(239)$ \\
\cline { 2 - 4 } & $\begin{array}{l}\text { DESIDERATIVE } \\
\text { IRREALIS }\end{array}$ & DES \\
\hline$\varnothing$ & IMPERATIVE & DEO & $(221)$ \\
\hline
\end{tabular}

\section{Languages with suffixes for mood marking}

Kayardild (Evans 1995)

\begin{tabular}{|l|ll|}
\hline Suffix & Modal meaning & \\
\hline IMPERATIVE & DEO $(2)$ & $(256)$ \\
\hline \multirow{2}{*}{ POTENTIAL } & EP & \\
& DEO & $(258-260)$ \\
\hline DESIDERATIVE & DES & \\
\hline HORTATIVE & DEO $(1,2,3)$ & $(262-263)$ \\
\hline APPREHENSIVE & DEO $(3)$ & $(263-264)$ \\
\hline
\end{tabular}

Mara (Heath 1981)

\begin{tabular}{|l|ll|}
\hline Suffix & Modal meaning & \\
\hline \multirow{2}{*}{ PAST POTENTIAL } & CF(IMM, DEO) & $(188)$ \\
& NEG(PST,PRS) & $(191)$ \\
\hline \multirow{2}{*}{ FUTURE } & FUT & $(184-186)$ \\
& NEG(FUT,DEO(2)) & $(191)$ \\
\hline IMPERATIVE & DEO(2) & $(188-189)$ \\
\hline DESIDERATIVE & DES & $(190)$ \\
\hline EVITATIVE & APPR & $(187)$ \\
\hline
\end{tabular}




\section{References}

Bybee, Joan (1998). 'Irrealis' as a grammatical category. Anthropological Linguistics 40: 257-271. Bybee, Joan, Revere Perkins, \& William Pagliuca (1994). The Evolution of Grammar: Tense, Aspect and Modality in the Languages of the World. Chicago: University of Chicago Press.

Capell, Arthur \& Heather Hinch (1970). Maung Grammar, Texts and Vocabulary. The Hague: Mouton.

Clendon, Mark (2000). A Grammar of Worrorra. Halls Creek: Kimberley Language Resource Centre.

Cook, Anthony (1987). Wagiman Watyin: A description of the Wagiman language of the Northern Territory. Doctoral dissertation, La Trobe University.

Dahl, Östen (1997). The relation between past time reference and counterfactuality: A new look. In Angeliki Athanasiadou \& René Dirven (eds.), On Conditionals Again, 97-114. Amsterdam: Benjamins.

Dixon, R. M. W. (2002). Australian Languages: Their Nature and Development. Cambridge: Cambridge University Press.

Dixon, R. M. W. \& Barry Blake (eds.) (2000). Handbook of Australian Languages. Volume 5. Oxford: Oxford University Press.

Eather, Bronwyn (1990). A grammar of Nakkara (central Arnhem Land coast). Doctoral dissertation, Australian National University.

Elliott, Jennifer R. (2000). Realis and irrealis: Forms and concepts of the grammaticalisation of reality. Linguistic Typology 4: 55-90.

Evans, Nicholas (1995). A Grammar of Kayardild. Berlin: Mouton.

- (2000). Iwaidjan, a very un-Australian language family. Linguistic Typology 4: 91-142.

- (2003a). Bininj Gun-Wok: A Pan-Dialectal Grammar of Mayali, Kunwinjku and Kune. (Pacific Linguistics, 541.) Canberra: Australian National University.

- (2003b). Introduction: Comparative non-Pama-Nyungan and Australian historical linguistics. In Evans (ed.) 2003, 3-25.

Evans, Nicholas (ed.) (2003). The Non-Pama-Nyungan Languages of Northern Australia: Comparative Studies of the Continent's most Linguistically Complex Region. (Pacific Linguistics, 552.) Canberra: Australian National University.

Fleischman, Susanne (1989). Temporal distance: A basic linguistic metaphor. Studies in Language 13: $1-50$.

Ford, Lysbeth (1998). A description of the Emmi language of the N. T. of Australia. Doctoral dissertation, Australian National University.

Givón, Talmy (1994). Irrealis and the subjunctive. Studies in Language 18: 265-337.

Green, Ian (1989). Marrithiyel: A language of the Daly River region of Australia's Northern Territory. Doctoral dissertation, Australian National University.

- (1995). The death of 'prefixing': Contact induced typological change in Northern Australia. Berkeley Linguistics Society 21: 414-425.

Green, Ian \& Rachel Nordlinger (2004). Revisiting Proto-Mirndi. In Claire Bowern \& Harold Koch (eds.), Australian Languages: Classification and the Comparative Method, 291-311. Amsterdam: Benjamins.

Grice, H. Paul (1975). Logic and conversation. In Peter Cole \& Jerry Morgan (eds.), Syntax and Semantics 3: Speech Acts, 41-58. New York: Academic Press.

Harvey, Mark (1986). The Waray language from Adelaide River. MA thesis, Australian National University.

- (1992). The Gaagudju people and their language. Doctoral dissertation, University of Sydney.

- (2001). A Grammar of Limilngan: A Language of the Mary River Region, Northern Territory, Australia. (Pacific Linguistics, 516.) Canberra: Australian National University.

- (2002). A Grammar of Gaagudju. Berlin: Mouton.

Heath, Jeffrey (1978). Ngandi Grammar, Texts, and Dictionary. Canberra: Australian Institute of Aboriginal Studies. 
- (1980a). Basic Materials in Warndarang: Grammar, Texts and Dictionary. (Pacific Linguistics, B-72.) Canberra: Australian National University.

- (1980b). Nunggubuyu Myths and Ethnographic Texts. Canberra: Australian Institute of Aboriginal Studies.

- (1981). Basic Materials in Mara: Grammar, Texts and Dictionary. (Pacific Linguistics, C-60.) Canberra: Australian National University.

- (1984). Functional Grammar of Nunggubuyu. Canberra: Australian Institute of Aboriginal Studies.

Horn, Larry (1989). A Natural History of Negation. Chicago: University of Chicago Press.

James, Deborah (1982). Past tense and the hypothetical: A cross linguistic study. Studies in Language 6: 375-403.

Keen, Sandra (1983). Yukulta. In R. M. W. Dixon \& Barry Blake (eds), Handbook of Australian Languages, Volume 3, 190-304. Amsterdam: Benjamins.

McGregor, William (1990). A Functional Grammar of Gooniyandi. Amsterdam: Benjamins.

- (1994). Warrwa. München: Lincom Europa.

- (2002). Verb Classification in Australian Languages. Berlin: Mouton.

McKay, Graham (1975). Rembarrnga, a language of central Arnhem Land. Doctoral dissertation, Australian National University.

- (2000). Ndjébbana. In Dixon \& Blake (eds.) 2000, 154-354.

Merlan, Francesca (1981). Some functional relations among subordination, mood, aspect and focus in Australian languages. Australian Journal of Linguistics 1: 175-210.

- (1982). Mangarayi. Amsterdam: North Holland.

- (1983). Ngalakan Grammar, Texts and Vocabulary. (Pacific Linguistics, B-89.) Canberra: Australian National University.

- (1994). A Grammar of Wardaman: A Language of the Northern Territory of Australia. Berlin: Mouton.

- (2003). The genetic position of Mangarrayi: Evidence from nominal prefixation. In Evans (ed.) 2003, 353-367.

Miestamo, Matti (2003). Clausal negation: A typological study. Doctoral dissertation, Helsingin yliopisto.

Mithun, Marianne (1995). On the relativity of irreality. In Joan Bybee \& Suzanne Fleischman (eds.), Modality in Grammar and Discourse, 367-388. Amsterdam: Benjamins.

Nordlinger, Rachel (1998). A Grammar of Wambaya, Northern Territory (Australia). (Pacific Linguistics, C-140.) Canberra: Australian National University.

- (2001). Wambaya in motion. In Jane Simpson, David Nash, Mary Langhren, Peter Austin, \& Barry Alpher (eds.), Forty Years On: Ken Hale and Australian Languages (Pacific Linguistics, 512), 401-413. Canberra: Australian National University.

Pym, Anthony \& Bonnie Larrimore (1979). Papers on Iwaidja Phonology and Grammar. (Work Papers of SIL-AAB, A-2.) Darwin: Summer Institute of Linguistics, Australian Aborigines Branch.

Rumsey, Alan (1982). An Intra-sentence Grammar of Ungarinjin, North-Western Australia. (Pacific Linguistics, B-86.) Canberra: Australian National University.

- (2000). Bunuba. In Dixon \& Blake (eds.) 2000, 34-152.

Saulwick, Adam (2003). Some lexicalizations and idiomatic expressions in Rembarrnga. Paper presented at the Blackwood Workshop on Australian Aboriginal Languages, University of Melbourne, March 14-26.

Schultze-Berndt, Eva (2000). Simple and Complex Verbs in Jaminjung: A Study of Event Categorization in an Australian Language. (MPI Series in Psycholinguistics, 14.) Nijmegen: MaxPlanck-Institut für Psycholinguistik.

Singer, Ruth (2003). Two verbal suffixes in Mawng, and their functions. Paper presented at the Seminar on Mood, Modality and Related Categories, University of Melbourne. 
Stokes, Bronwyn (1982). A description of Nyikina, a language of the West Kimberley, Western Australia. Doctoral dissertation, Australian National University.

Traugott, Elizabeth \& Richard Dasher (2001). Regularity in Semantic Change. Cambridge: Cambridge University Press.

Van der Auwera, Johan \& Vladimir Plungian (1998). Modality’s semantic map. Linguistic Typology 2: 79-124.

Verstraete, Jean-Christophe (2001). Subjective and objective modality. Journal of Pragmatics 33: 1505-1528.

- (forthcoming). The nature of irreality in the past domain: Evidence from past intentional constructions in Australian languages. To appear in Australian Journal of Linguistics.

Verstraete, Jean-Christophe \& An van Linden (2004). The nature of counterfactuality in simple clauses: Cross-linguistic evidence. Unpublished manuscript, Katholieke Universiteit Leuven.

Wilson, Stephen (1999). Coverbs and Complex Predicates in Wagiman. Stanford: CSLI.

Ziegeler, Debra (2000). Hypothetical Modality: Grammaticalisation in an L2 Dialect. Amsterdam: Benjamins. 